\title{
ANALISIS KUALITAS SISTEM LAYANAN PENILAIAN BUKU PENDIDIKAN AGAMA (SiLPBPA) MENGGUNAKAN METODE SYSTEM USABILITY SCALE (SUS) DAN PENGEMBANGANNYA MENGGUNAKAN SCRUM BERBASIS WEB
}

\author{
Asep Erlan Maulana ${ }^{1}$, Abu Khalid Rivai ${ }^{2}$, Sarwani Sarwani ${ }^{3}$ \\ 1,2Pascasarjana Magister Komputer Teknik Informatika \\ Sekolah Tinggi Manajemen Informatika dan Komputer Eresha \\ ${ }^{3}$ Pascasarjana Magister Manajemen \\ Universitas Pamulang Tangerang Selatan, Banten, Indonesia \\ ${ }^{1}$ ceperlan@gmail.com, ${ }^{2}$ dosen40042@eresha.ac.id, ${ }^{3}$ sarwani3082@yahoo.com
}

\begin{abstract}
SiLPBPA version 1.0 is implemented in the Religious Education Book Assessment Service activities. However, there are many obstacles and problems, namely that some system functions do not match the needs that support their activities. The purpose of this research is to conduct quality analysis and develop SiLPBPA. The methodology for conducting quality analysis is the System Usability Scale (SUS), and its development uses the Agile method with a Scrum framework. The results show that the system's quality gets a score of 71 , which means the system is Acceptable, is in Predicate C, and with a good rating. However, some users gave some suggestions on the questionnaire. These suggestions are evaluated, which are used as the basis for system development. The results of developing using Scrum can be completed within 65 hours of the target time of 70 hours shown on the Burndown Chart. Some system functions can be completed properly. This was proven at the Sprint Review event, the Scrum Team and Stakeholders who attended approved the Product Increments that had been developed in all Sprints. So that SiLPBPA can be used in the next Education Book Assessment service activities.
\end{abstract}

Keywords: SiLPBPA, System Usability Scale (SUS), Scrum

\begin{abstract}
ABSTRAK
SiLPBPA versi 1.0 diimplementasikan pada kegiatan Layanan Penilaian Buku Pendidikan Agama. Namun, terdapat banyak kendala dan permasalahan yaitu beberapa fungsi pada sistem tidak sesuai dengan kebutuhan yang mendukung kegiatannya. Tujuan penelitian ini adalah untuk melakukan analisis kualitas dan melakukan pengembangan sistem. Metodologi untuk melakukan analisis kualitas adalah System Usability Scale (SUS) dan pengembangannya menggunakan metode Agile dengan kerangka kerja Scrum. Hasil penelitian menunjukkan pada kualitas sistem mendapatkan skor 71 yang berarti sistem dapat diterima (Acceptable), ada pada Predikat C, dan dengan Rating Good. Namun beberapa user memberikan beberapa saran pada kuesioner. Saran tersebut dilakukan evaluasi yang dijadikan dasar untuk melakukan pengembangan sistem. Hasil dari pengembangan menggunakan Scrum bisa diselesaikan dalam waktu 65 jam dari target waktu 70 jam yang terlihat pada Burndown Chart. Beberapa fungsi sistem dapat selesai dengan baik. Hal ini terbukti pada acara Sprint Review, Tim Scrum dan Stakeholder yang hadir menyetujui Product Increment yang sudah dikembangkan pada semua Sprint, sehingga SiLPBPA dapat digunakan pada kegiatan layanan Penilaian Buku Pendidikan selanjutnya.
\end{abstract}

Kata Kunci: SiLPBPA, System Usability Scale (SUS), Scrum 


\section{PENDAhuluan}

Dalam Peraturan Menteri Agama Republik Indonesia Nomor 9 Tahun 2018 [1] tentang Buku Pendidikan Agama disebutkan bahwa Badan Litbang dan Diklat Kementerian Agama melaksanakan penilaian buku pendidikan agama. Dalam melaksanakan tugasnya Badan Litbang dan Diklat Kementerian Agama, mengeluarkan SK Kepala Badan Litbang dan Diklat Kementerian Agama Nomor 51 Tahun 2018 [2] tentang penulisan, penilaian, dan penerbitan buku Pendidikan Agama. Di dalam SK tersebut menunjuk Puslitbang Lektur, Khazanah dan Manajemen Organisasi sebagai stakeholder yang melaksanakan penilaian buku Pendidikan Agama.

Pada awalnya, kegiatan ini dilakukan secara manual. Stakeholder bertemu dalam satu waktu dan satu tempat. Para penerbit datang ke kantor Puslitbang Lektur, Khazanah dan Manajemen Organisasi untuk melakukan pendaftaran dengan menyerahkan kelegalan perusahaan dan buku dalam bentuk hardcopy, kemudian dilakukan penilaian oleh para penilai sampai buku layak terbit dan mendapatkan lembar persetujuan terbit. Hal ini sangat merepotkan stakeholder yang terlibat dalam kegiatan ini. Oleh karena itu, tahun 2018 Puslitbang Lektur, Khazanah Keagamaan dan Manajemen Organisasi melakukan pengembangan sebuah aplikasi. Aplikasi ini dinamakan SiLPBPA (Sistem Layanan Penilaian Buku Pendidikan Agama). Versi 1.0 dari sistem ini hanya untuk melayani pendaftaran dan penerbit menyerahkan kelegalan perusahaan secara daring. Pada implementasinya, sistem ini banyak kendala dan permasalahan didalam penggunaanya. Beberapa fungsi sistem tidak sesuai dengan kebutuhan yang mendukung pada kegiatannya.

Dari permasalahan tersebut maka perlu dilakukan analisis kualitas layanan dan pengembangan sistem. Dalam melakukan analisis kualitas layanan dari SiLPBPA diperlukan tes kegunaan untuk melakukan evaluasi dari sebuah produk perangkat lunak yang sudah dibuat [3]. Di dalam ilmu UX (User Experience) terdapat pembahasan pengukuran tingkat kegunaan (Usability). Artinya kegiatan ini dilakukan untuk mengukur tingkat kegunaan sebuah sistem yang dilihat dari berbagai aspek kepuasan pengguna [4]. Salah satu dalam melakukan pengujian kegunaan adalah menggunakan System Usability Scale (SUS).
System Usability Scale (SUS) adalah satu metode untuk melakukan evaluasi sebuah produk perangkat lunak dengan pertimbangan jumlah sampel yang kecil, waktu dan biaya yang memberikan hasil yang memadai [5]. Menurut Martoyo dan Falahah [6], System Usability Scale (SUS) merupakan sebuah teknik pengujian kegunaan sebuah perangkat lunak yang dalam proses pengerjaanya melibatkan pengguna akhir. Bisa membedakan kegunaan perangkat lunak dengan biaya murah dan terjangkau serta dapat diandalkan hasilnya meskipun dengan jumlah sampelnya yang lebih sedikit [7].

Setelah melakukan pengujian di dalam penggunaan sistem, tahap selanjutnya adalah melakukan pengembangan sistem dengan kerangka kerja Scrum. Scrum diplih karena salah satu kerangka kerja yang populer dari metode pengembangan sistem Agile [8]. Scrum dapat mengatasi masalah kompleks, menghantarkan produk dengan setinggi mungkin secara produktif dan kreatif [9]. Di dalam penelitian Murdiani, Yudhana dan Sunardi [10], yang dirilis oleh The Standish Group antara tahun 2002-2010 menunjukkan metode Agile lebih sukses tingkat keberhasilannya sebanyak $42 \%$ dibandingkan dengan metode lain seperti Waterfall $14 \%$. Kerangka kerja Scrum banyak digunakan di dalam pengembangan perangkat lunak [11][12][13]. Dapat lebih cepat memprediksi untuk mengetahui resiko dan kualitas dari pengembangan perangkat lunak [14]. Masalah yang terjadi pada proses pengembangan bisa diketahui secara cepat [15]. Menyelesaikan pengembangan sistem secara realtime dengan cepat. Umpan balik dari user dengan cepat dan dapat merilis produk di setiap akhir sprint-nya [16]. Bersifat ringan, sederhana dan dengan pendekatan bottom up [17].

Beberapa penelitian yang melakukan kajian tentang menguji kualitas, hanya sampai pengujian usability perangkat lunaknya saja tidak sampai tahap pengembangan. Oleh karena itu, penulis melakukan penelitian ini bertujuan untuk analisis kualitas usability aplikasi SiLPBPA versi 1.0 menggunakan System Usabily Scale (SUS) dan melakukan pengembangan sistem dari hasil uji kualitas menggunakan Scrum. Agar sistem tersebut dapat segera digunakan langsung dengan baik dan efektif yang sesuai dengan kebutuhan 
penggunanya pada kegiatan yang segera dilaksanakan.

\section{METODOLOGI}

Penelitian ini diawali dengan melakukan observasi selama kegiatan layanan penilaian buku Pendidikan Agama sedang berlangsung dari awal bulan Januari sampai bulan Desember 2019. Kemudian melakukan studi pustaka dengan mengumpulkan dan mengkaji beberapa artikel dari jurnal ilmiah nasional maupun jurnal internasional. Beberapa buku, artikel hasil publikasi pada conference, dan sumbersumber terpercaya dari internet yang dapat mendukung dalam proses penelitian ini.

Metode pengumpulan data yang digunakan adalah menggunakan kuesioner dari instrumen data kuesioner System Usabily Scale (SUS). Kuesioner disebarkan secara daring menggunakan Google Form kepada pengguna yang terlibat didalam sistem yaitu Admin, Operator dan Penerbit. Kuesioner terdiri dari 10 item pertanyaan dengan menggunakan skala 5 jawaban.

Tabel 1. Instrumen data kuesioner SUS [18]

\begin{tabular}{|c|c|c|}
\hline Kode & Instrumen Pertanyaan & Skala \\
\hline Q1 & $\begin{array}{l}\text { 1. Saya berpikir akan sering } \\
\text { menggunakan sistem ini. }\end{array}$ & $1-5$ \\
\hline Q2 & $\begin{array}{l}\text { 2. Saya rasa sistem ini rumit } \\
\text { untuk digunakan. }\end{array}$ & $1-5$ \\
\hline Q3 & $\begin{array}{l}\text { 3. Saya rasa sistem ini mudah } \\
\text { digunakan. }\end{array}$ & $1-5$ \\
\hline Q4 & $\begin{array}{l}\text { 4. Saya membutuhkan bantuan } \\
\text { dari orang lain atau teknisi } \\
\text { untuk dapat menggunakan } \\
\text { sistem ini. }\end{array}$ & $1-5$ \\
\hline Q5 & $\begin{array}{l}\text { 5. Saya rasa fitur dari berbagai } \\
\text { fungsi sistem ini berjalan } \\
\text { sebagaimana mestinya. }\end{array}$ & $1-5$ \\
\hline Q6 & $\begin{array}{l}\text { 6. Saya menemukan sistem ini } \\
\text { tidak konsisten. }\end{array}$ & $1-5$ \\
\hline Q7 & $\begin{array}{l}\text { 7. Saya rasa kebanyakan orang } \\
\text { akan mudah belajar untuk } \\
\text { menggunakan sistem ini } \\
\text { dengan sangat cepat. }\end{array}$ & $1-5$ \\
\hline Q8 & $\begin{array}{l}\text { 8. Saya rasa sistem ini sangat } \\
\text { rumit untuk digunakan. }\end{array}$ & $1-5$ \\
\hline Q9 & $\begin{array}{l}\text { 9. Saya rasa tidak ada } \\
\text { hambatan dalam } \\
\text { menggunakan sistem ini. }\end{array}$ & $1-5$ \\
\hline Q10 & $\begin{array}{l}\text { 10. Saya perlu membiasakan diri } \\
\text { terlebih dahulu sebelum bisa } \\
\text { memulai menggunakan } \\
\text { sistem ini. }\end{array}$ & $1-5$ \\
\hline
\end{tabular}

Tabel 2. Skor jawaban pertanyaan kuesioner

\begin{tabular}{cc}
\multicolumn{2}{c}{ SUS } \\
\hline Jawaban & Skor \\
\hline Sangat Tidak Setuju (STS) & 1 \\
Tidak Setuju (TS) & 2 \\
Ragu-Ragu (RG) & 3 \\
Setuju (S) & 4 \\
Sangat Setuju & 5 \\
\hline
\end{tabular}

Kalimat dengan pertanyaan positif (pada instrumen pertanyaan ganjil. Kode: Q1, Q3, Q5, Q7, Q9), skor kontribusinya adalah posisi skala dikurangi 1. Kalimat dengan pertanyaan negatif (pada instrumen pertanyaan genap. Kode: Q2,Q4,Q6,Q8,Q10), skor kontribusinya adalah 5 dikurangi posisi skala [19].

Skor $S U S=((Q 1-1)+(5-Q 2)+(Q 3-1)+$ $(5-Q 4)+(Q 5-1)+(5-Q 6)+(Q 7-1)+(5$ $-Q 8)+(Q 9-1)+(5-Q 10)) * 2,5)$

Nilai keseluruhan Usability didapat dari skor kontribusi yang berkisar antara 0 sampai 4 dikalikan 2,5. Persamaan 1 adalah rumus perhitungan skor SUS secara keseluruhan [20]:

$$
\begin{gathered}
\bar{X}=\frac{\sum \chi}{n} \\
\bar{X}=\text { skor rata }- \text { rata } \\
\sum_{n=\text { jumlah responden }} \chi=\text { jumlah skor } S U S
\end{gathered}
$$

Nilai keseluruhan Skor diperoleh dari ratarata skor SUS individual [19]. Rentang skor SUS yang dimiliki adalah dari 0 sampai 100 [21]. Ada 2 cara dalam melakukan penentuan hasil akhir penilaian [22]. (1) Penentuan hasil yang menggunakan skor Percentile Rank [23]. Menurut Ependi [24] skor Percentile Rank ditentukan ke dalam grade penilaian yang ditunjukkan pada Tabel 3.

Tabel 3. Grade penilaian skor SUS percentile rank

\begin{tabular}{cl}
\hline Grade & \multicolumn{1}{c}{ Skor } \\
\hline A & Skor lebih besar atau sama dengan 80,3 \\
B & $\begin{array}{l}\text { Skor lebih besar sama dengan 74 dan } \\
\text { lebih kecil 80,3 }\end{array}$ \\
C & Skor lebih besar 68 dan lebih kecil 74 \\
D & Skor lebih besar sama dengan 51 dan \\
& lebih kecil 68 \\
E & Skor lebih kecil dari 51 \\
\hline
\end{tabular}

(2) Penentuan hasil yang menggunakan Acceptability Range, Grade Scale, dan 
Adjective Rating [25]. Terdapat 3 kategori penerimaan anggota pada Acceptability Range yaitu acceptable, marginal, not acceptable. Pada Grade Scale ada 6 skala tingkat penerimaan pengguna yaitu $\mathrm{A}, \mathrm{B}, \mathrm{C}, \mathrm{D}$, dan $\mathrm{F}$. dan tingkat penerimaan pengguna pada Adjective Rating adalah worst imaginable, poor, good, excellent, dan best imaginable.

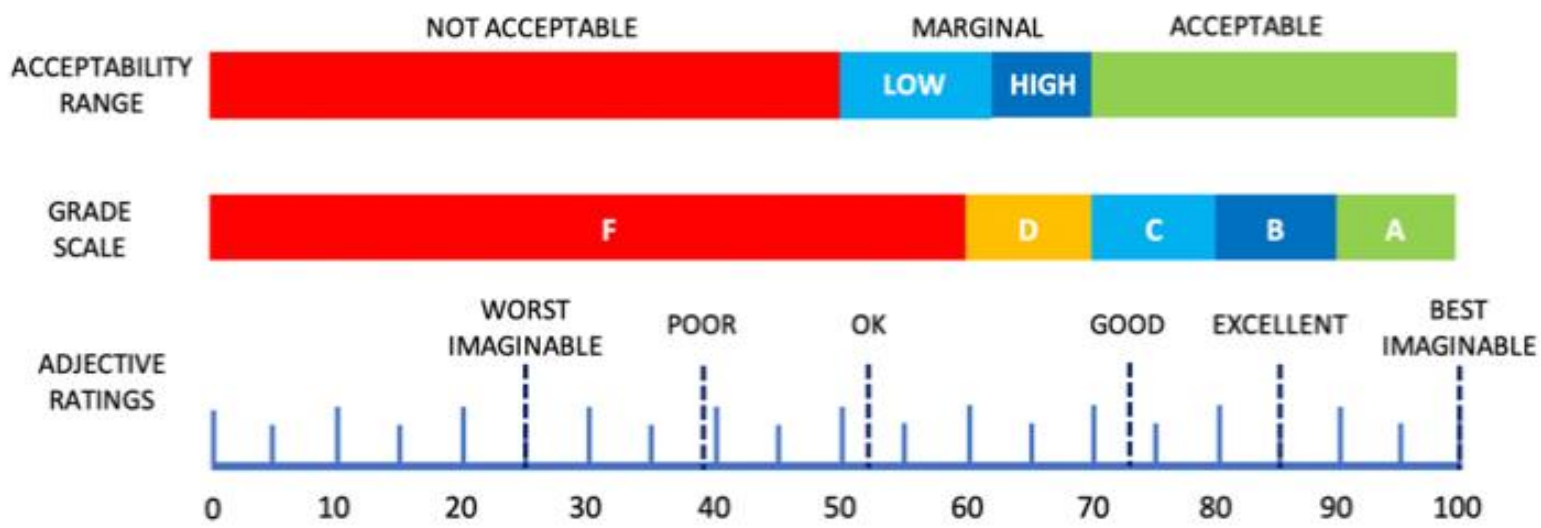

Gambar 1. Kategori skor SUS acceptability range, grade scale, dan adjective rating [25]

Pengembangan sistem menggunakan metode Agile dengan kerangka kerja Scrum. Menurut Rubin [26] ada beberapa tahapan dalam pelaksanaan Scrum antara lain (Gambar 2): (1) Product Backlog Groaming adalah kegiatan untuk membuat, mengidentifikasi, mengatur prioritas dan memperbaiki Product Backlog Item. (2) Sprint Planning adalah kegiatan kolaboratif (oleh seluruh anggota tim Scrum) untuk memproses perencanaan pekerjaan yang akan dilakukan dalam satu sprint. Output kegiatan ini adalah Sprint Goal dan Sprint Backlog (3) Sprint Execution kegiatan untuk memenuhi tujuan Sprint (Sprint Goal) yang dilakukan oleh Tim Scrum. Setiap Sprint waktu maksimum penyelesaiannya 1 bulan dengan durasi 8 jam. (4) Daily Scrum adalah kegiatan yang dilakukan oleh Development Team untuk evaluasi, kendala aktifitas yang sudah dilakukan dan rencana ke depannya untuk mencapai Sprint Goal dengan durasi waktu 15 menit selama sprint berlangsung. (5) Sprint Review adalah kegiatan diskusi antara Tim Scrum dengan stakeholder (Pemegang Kepentingan) untuk melakukan review pekerjaan yang sudah diselesaikan oleh Development Team selama satu sprint. (6) Sprint Retrospective adalah kegiatan untuk menginspeksi dirinya sendiri (Development Team) dan membuat perencanaan agar pada sprint selanjutnya meningkatkan pekerjaan yang dilakukan. Durasi waktu penyelenggaraan dalam 1 bulan adalah 3 jam.

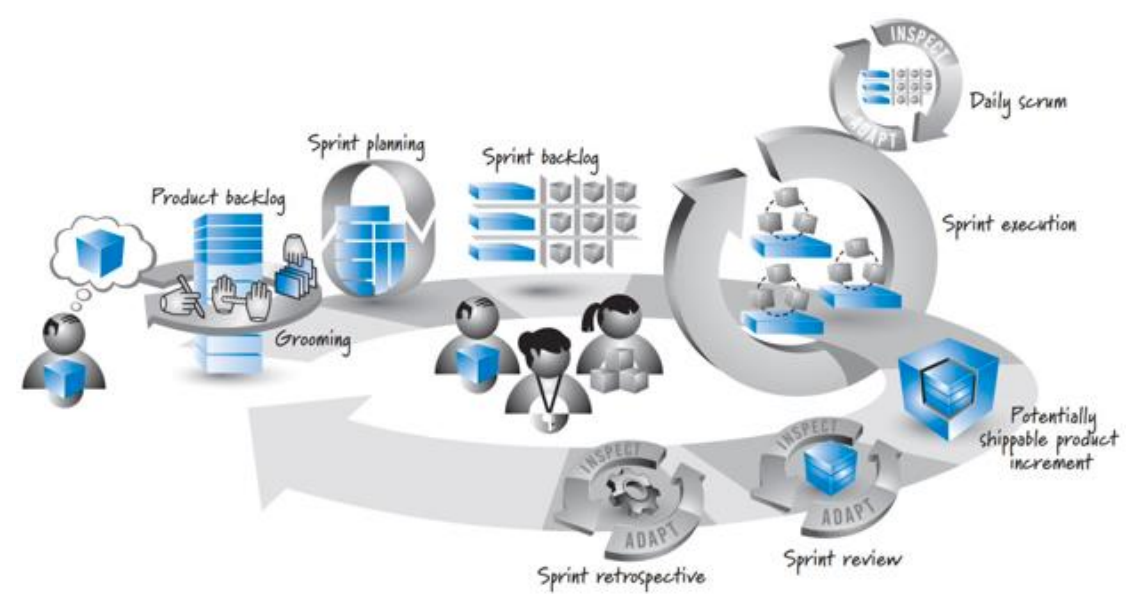

Gambar 2. Tahapan pelaksanaan scrum [26]. 
Alur tahapan keseluruhan dari penelitian ini adalah sebagai berikut:

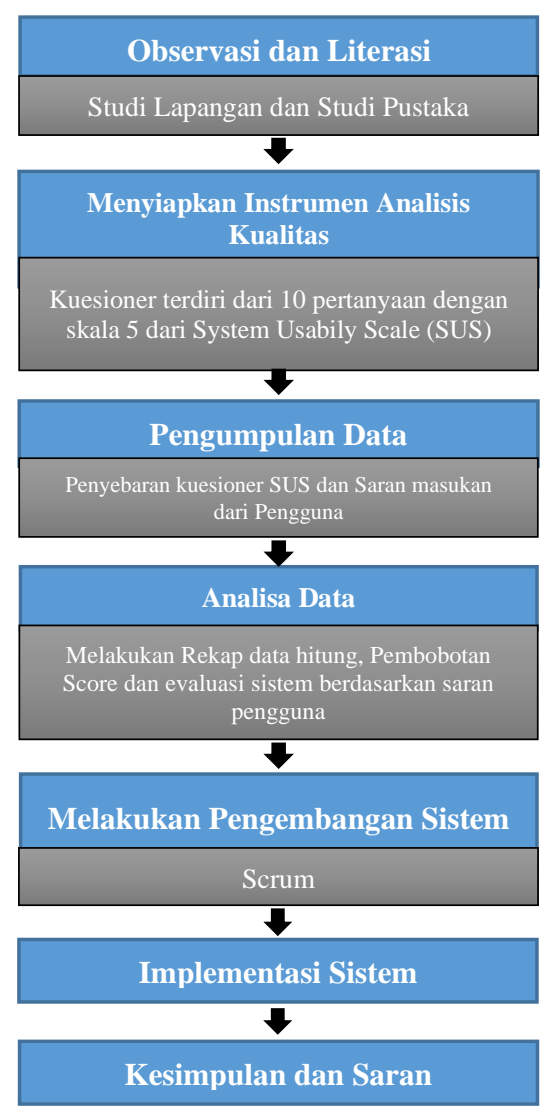

Gambar 3. Alur proses penelitian

\section{HASIL DAN PEMBAHASAN}

\subsection{Data Penelitian}

Hasil pengumpulan data dari kuesioner pada tanggal 17 Maret 2019 adalah sebanyak 14
Responden yang terdiri dari user Admin dan Operator berjumlah 5 orang dan user Penerbit berjumlah 9 orang. Berikut adalah rincian data tersebut:

Tabel 4. Data kuesioner dari responden

\begin{tabular}{|c|c|c|c|c|c|c|c|c|c|c|c|}
\hline \multirow{2}{*}{ No } & \multirow{2}{*}{ Responden } & \multicolumn{10}{|c|}{ Skor Kuisioner dari responden } \\
\hline & & Q1 & Q2 & Q3 & Q4 & Q5 & Q6 & Q7 & Q8 & Q9 & Q10 \\
\hline 1 & Responden 1 & 4 & 2 & 4 & 2 & 2 & 4 & 2 & 2 & 2 & 4 \\
\hline 2 & Responden 2 & 4 & 2 & 4 & 2 & 3 & 3 & 3 & 2 & 3 & 4 \\
\hline 3 & Responden 3 & 4 & 2 & 4 & 4 & 3 & 3 & 4 & 3 & 4 & 4 \\
\hline 4 & Responden 4 & 5 & 2 & 4 & 3 & 4 & 2 & 4 & 2 & 4 & 5 \\
\hline 5 & Responden 5 & 4 & 2 & 4 & 2 & 4 & 3 & 4 & 2 & 4 & 4 \\
\hline 6 & Responden 6 & 5 & 2 & 4 & 3 & 3 & 3 & 3 & 3 & 3 & 4 \\
\hline 7 & Responden 7 & 5 & 2 & 4 & 2 & 4 & 2 & 4 & 2 & 4 & 4 \\
\hline 8 & Responden 8 & 5 & 2 & 4 & 2 & 4 & 2 & 4 & 2 & 4 & 4 \\
\hline 9 & Responden 9 & 5 & 2 & 4 & 2 & 4 & 2 & 4 & 2 & 4 & 2 \\
\hline 10 & Responden 10 & 4 & 2 & 4 & 2 & 4 & 3 & 3 & 2 & 4 & 4 \\
\hline 11 & Responden 11 & 4 & 2 & 4 & 2 & 2 & 2 & 4 & 2 & 4 & 4 \\
\hline 12 & Responden 12 & 4 & 2 & 4 & 2 & 4 & 2 & 4 & 2 & 4 & 4 \\
\hline 13 & Responden 13 & 4 & 2 & 4 & 2 & 3 & 2 & 4 & 2 & 4 & 4 \\
\hline 14 & Responden 14 & 4 & 2 & 4 & 2 & 4 & 2 & 4 & 2 & 4 & 2 \\
\hline
\end{tabular}




\subsection{Melakukan Perhitungan dengan Rumus \\ SUS}

Data hasil kuesioner yang diperoleh dari responden pada Tabel 4 dilakukan perhitungan dengan rumus SUS per responden [19] dan keseluruhan [20]. Diketahui rumus perhitungan Skor SUS per responden adalah:

Skor SUS $=((Q 1-1)+(5-Q 2)+(Q 3-1)+$ $(5-Q 4)+(Q 5-1)+(5-Q 6)+(Q 7-1)+(5$ $-Q 8)+(Q 9-1)+(5-Q 10)) * 2.5)$
Kemudian dari hasil perhitungan dengan rumus per responden dihitung dengan rumus secara keseluruhan:

$$
\begin{aligned}
& 50+60+58+68+68+58+73+ \\
\bar{x} & =\frac{73+78+65+65+70+68+75}{14} \\
\bar{x} & =\frac{925}{14} \\
\bar{x} & =71
\end{aligned}
$$

\begin{tabular}{|c|c|c|c|c|c|c|c|c|c|c|c|c|}
\hline \multirow{2}{*}{ Responden } & \multicolumn{10}{|c|}{ Skor Hasil Hitung SUS } & \multirow{2}{*}{ Jumlah } & \multirow{2}{*}{$\begin{array}{c}\text { Nilai } \\
(\text { Jumlah x 2.5) }\end{array}$} \\
\hline & Q1 & Q2 & Q3 & Q4 & Q5 & Q6 & Q7 & Q8 & Q9 & Q10 & & \\
\hline $\mathrm{R} 1$ & 3 & 3 & 3 & 3 & 1 & 1 & 1 & 3 & 1 & 1 & 20 & 50 \\
\hline $\mathrm{R} 2$ & 3 & 3 & 3 & 3 & 2 & 2 & 2 & 3 & 2 & 1 & 24 & 60 \\
\hline $\mathrm{R} 3$ & 3 & 3 & 3 & 1 & 2 & 2 & 3 & 2 & 3 & 1 & 23 & 58 \\
\hline $\mathrm{R} 4$ & 4 & 3 & 3 & 2 & 3 & 3 & 3 & 3 & 3 & 0 & 27 & 68 \\
\hline R5 & 3 & 3 & 3 & 3 & 3 & 2 & 3 & 3 & 3 & 1 & 27 & 68 \\
\hline R6 & 4 & 3 & 3 & 2 & 2 & 2 & 2 & 2 & 2 & 1 & 23 & 58 \\
\hline R7 & 4 & 3 & 3 & 3 & 3 & 3 & 3 & 3 & 3 & 1 & 29 & 73 \\
\hline $\mathrm{R} 8$ & 4 & 3 & 3 & 3 & 3 & 3 & 3 & 3 & 3 & 1 & 29 & 73 \\
\hline R9 & 4 & 3 & 3 & 3 & 3 & 3 & 3 & 3 & 3 & 3 & 31 & 78 \\
\hline $\mathrm{R} 10$ & 3 & 3 & 3 & 3 & 3 & 2 & 2 & 3 & 3 & 1 & 26 & 65 \\
\hline $\mathrm{R} 11$ & 3 & 3 & 3 & 3 & 1 & 3 & 3 & 3 & 3 & 1 & 26 & 65 \\
\hline $\mathrm{R} 12$ & 3 & 3 & 3 & 3 & 3 & 3 & 3 & 3 & 3 & 1 & 28 & 70 \\
\hline $\mathrm{R} 13$ & 3 & 3 & 3 & 3 & 2 & 2 & 3 & 3 & 3 & 1 & 26 & 65 \\
\hline R14 & 3 & 3 & 3 & 3 & 3 & 3 & 3 & 3 & 3 & 3 & 30 & 75 \\
\hline & & & & kor ra & -rata & Hasil & khir) & & & & & 71 \\
\hline
\end{tabular}

Tabel 5. Hasil perhitungan skor SUS

\subsection{Analisis Skor SUS}

Hasil perhitungan dari skor System Usability Scale (SUS) menunjukkan Skor SUS akhir ratarata sebesar 71. Berdasarkan penentuan hasil yang menggunakan skor Percentile Rank masuk ke dalam predikat $\mathrm{C}$, sedangkan berdasarkan penentuan hasil menggunakan Acceptability Range masuk ke dalam kategori Acceptable. Pada Grade Scale masuk ke dalam kategori C dan pada Adjective Rating masuk ke dalam kategori Good. 


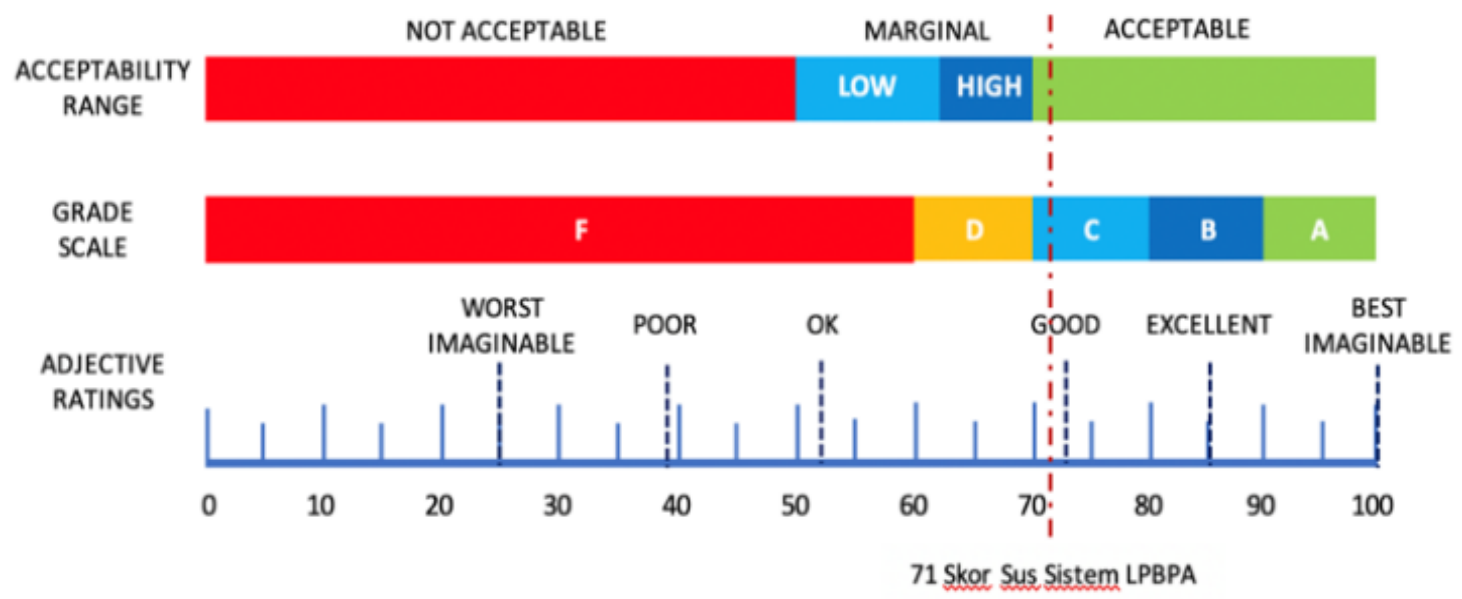

Gambar 4. Hasil nilai skor SUS pada acceptability range, grade scale, dan adjective rating

Dari hasil tersebut, maka dapat disimpulkan bahwa SiLPBPA dapat digunakan oleh pengguna. Skor SUS rata-rata 82 atau lebih berpotensi pengguna menjadi Promoter dan potensi pengguna menjadi Deductor, jika skor SUS rata-rata 67 atau kurang. Hal ini dilakukan karena skor SUS bisa dikorelasikan dengan Net Promoter menurut penjelasan Sauro [27]. Hasil skor SUS SiLPBPA adalah 71. Skor ini ada di antara Promoter dan Deductor namun cenderung penggunanya Deductor, sehingga menyebabkan penurunan jumlah pengguna.

Penilaian Subyektif dari hasil nilai skor SUS pada sistem ini belum memenuhi kebutuhan pengguna. Hal ini berdasarkan 6 saran dari pengguna yang dicantumkan pada hasil kuesioner: (1) Di setiap tahapannya belum adanya petunjuk yang aplikatif (2) FAQ belum ada (3) pada unggah berkas, tidak ada informasi jenis file dan size (4) Beberapa konten ditambahkan antara lain atribut lengkap pada komponen buku dengan melengkapi identitas dan id supaya tidak ada duplikat buku dengan judul yang sama (5) Seharusnya user admin dapat menghapus user operator (6) Seharusnya ditambahkan atribut Jenis Buku, Tahun Terbit, Jenjang Pendidikan dan kelas sesuai dengan metadata buku dari penerbit.

\subsection{Melakukan Pengembangan Sistem dengan Scrum}

Berdasarkan hasil analisis skor SUS dan masukan dari pengguna maka penulis melakukan evaluasi pada sistem. Berikut adalah evaluasi permasalahan dan penyelesaiannya:

Tabel 6. Evaluasi sistem berdasarkan analisis skor SUS dan saran dari user

\begin{tabular}{|c|c|}
\hline Permasalahan & Penyelesaian \\
\hline $\begin{array}{l}\text { Belum adanya petunjuk penggunaan untuk } \\
\text { penerbit }\end{array}$ & $\begin{array}{l}\text { Menampilkan petunjuk penggunaan pada } \\
\text { halaman utama sistem dan penerbit bisa men- } \\
\text { download-nya }\end{array}$ \\
\hline Belum adanya menu & Menampilkan menu Frequently Asked \\
\hline Frequently Asked Question (FAQ) & Question (FAQ) pada halaman utama sistem \\
\hline $\begin{array}{l}\text { Tidak ada informasi jenis file dan size } \\
\text { dalam mengunggah berkas syarat bagi } \\
\text { penerbit }\end{array}$ & $\begin{array}{l}\text { Menampilkan informasi jenis file dan size pada } \\
\text { menu berkas syarat bagi user Penerbit }\end{array}$ \\
\hline Terdapat duplikat data karena identitas & Menambahkan isian untuk kelengkapan \\
\hline $\begin{array}{l}\text { Buku Pendidikan Agama tidak lengkap dan } \\
\text { tanpa id }\end{array}$ & $\begin{array}{l}\text { identitas data buku Pendidikan Agama yang } \\
\text { akan dinilai agar tidak terjadinya duplikat data }\end{array}$ \\
\hline Admin tidak dapat menghapus data operator & $\begin{array}{c}\text { Menambahkan menu delete data operator pada } \\
\text { user Admin }\end{array}$ \\
\hline $\begin{array}{l}\text { Pada data buku seharusnya ditambahkan } \\
\text { atribut Jenis Buku, Tahun Terbit, Jenjang }\end{array}$ & $\begin{array}{l}\text { Menambahkan isian kolom data buku pada } \\
\text { atribut Jenis Buku, Tahun Terbit, Jenjang }\end{array}$ \\
\hline $\begin{array}{l}\text { Pendidikan dan kelas sesuai dengan } \\
\text { metadata buku dari penerbit }\end{array}$ & $\begin{array}{c}\text { Pendidikan dan kelas sesuai dengan metadata } \\
\text { buku dari penerbit }\end{array}$ \\
\hline
\end{tabular}


Penyelesaian dari permasalahan pada tabel 6 adalah perlunya pengembangan pada SiLPBPA. Pengembangan dilakukan menggunakan kerangka kerja Scrum dan aplikasi Trello. Trello adalah alat kolaborasi visual yang digunakan sebagai papan tulis, sticky notes dan spidol virtual untuk menyelesaikan pengembangan SiLPBA bersama-sama secara fleksibel tanpa pembatasan ruang dan waktu dan tanpa pertemuan fisik [28]. Aplikasi ini digunakan karena selama pengembangan sistem, tim Scrum tidak dalam satu lokasi. Sehingga semua informasi bisa dengan mudah dan cepat diketahui oleh tim.

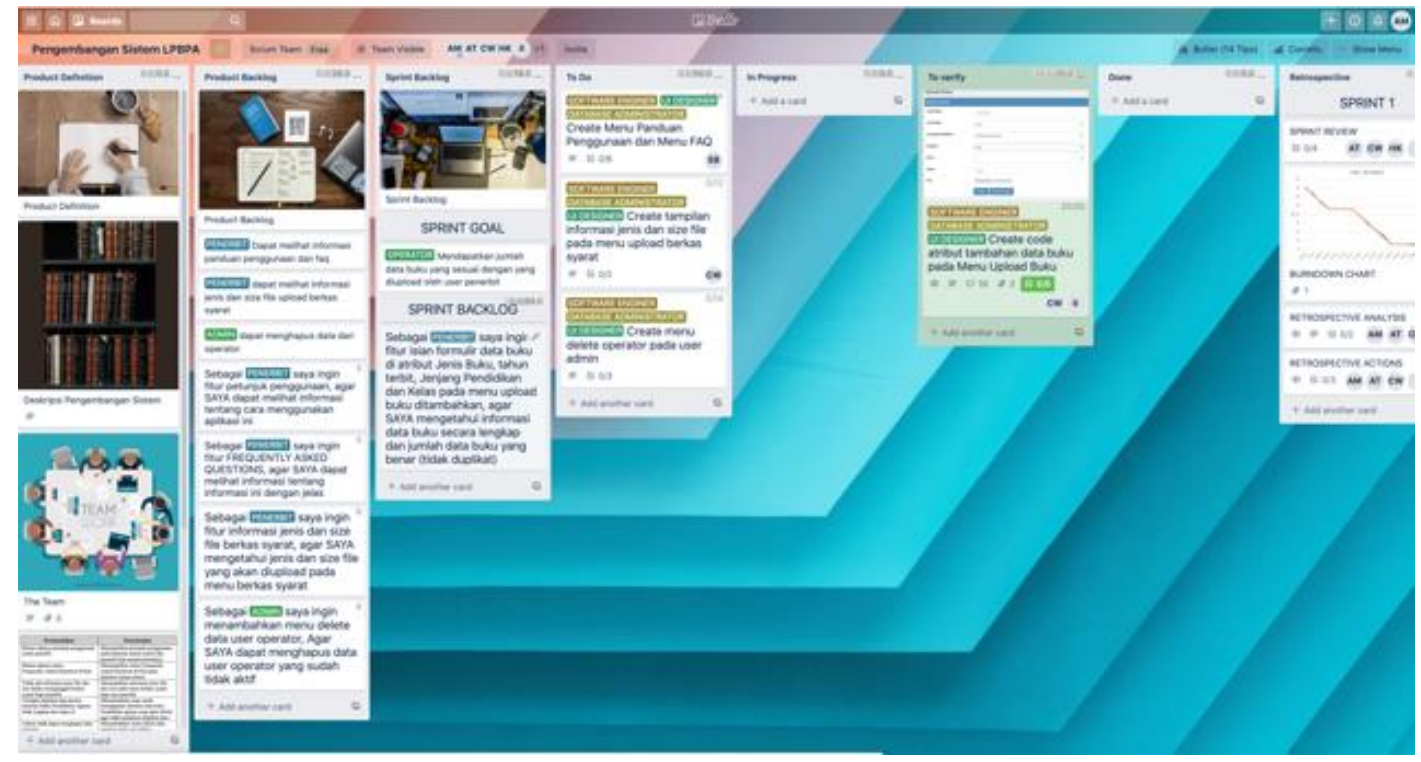

Gambar 5. Proses pengembangan SiLPBPA menggunakan aplikasi Trello

\subsection{Menentukan Product Backlog}

Product Owner (PO) membuat daftar, mengklasifikasi dan mengatur prioritas dari Product Backlog Item (PBI). Daftar PBI dibuat atas hasil evaluasi pada Tabel 6. PO melakukan kolaborasi dengan Development Team (DT) dalam kegiatan ini. Berikut adalah hasilnya:

Tabel 7. Product backlog

\begin{tabular}{llcc}
\hline No & \multicolumn{1}{c}{ Deskripsi Fitur yang akan Dikembangkan (PBI) } & Prioritas & $\begin{array}{c}\text { Estimasi } \\
\text { Waktu } \\
\text { (jam) }\end{array}$ \\
\hline 1 & $\begin{array}{l}\text { Menampilkan Menu Panduan Penggunaan pada halaman utama } \\
\text { Menampilkan Menu Frequently Asked Question (FAQ) pada halaman } \\
\text { utama }\end{array}$ & $\begin{array}{c}\text { Prioritas } \\
\text { Prioritas }\end{array}$ & 12 \\
3 & $\begin{array}{l}\text { Menambahkan isian kolom data buku pada atribut Jenis Buku, Tahun } \\
\text { Terbit, Jenjang Pendidikan dan kelas sesuai dengan metadata buku dari } \\
\text { penerbit sehingga identitas data buku lengkap dan tidak duplikat } \\
\text { Menampilkan informasi jenis file dan size pada menu berkas syarat bagi } \\
\text { user penerbit }\end{array}$ & Prioritas & 20 \\
Menambahkan menu delete data user operator pada user admin & Prioritas & 12 \\
\hline
\end{tabular}


Kemudian PBI dibuat menjadi user story untuk dimasukkan pada aplikasi Trello.

\begin{tabular}{|c|c|}
\hline \multicolumn{2}{|c|}{$\begin{array}{l}\text { Sebagai PENERBIT saya ingin } \\
\text { fitur isian formulir data buku } \\
\text { di atribut Jenis Buku, tahun } \\
\text { terbit, Jenjang Pendidikan } \\
\text { dan Kelas pada menu upload } \\
\text { buku ditambahkan, agar } \\
\text { SAYA mengetahui informasi } \\
\text { data buku secara lengkap } \\
\text { dan jumlah data buku yang } \\
\text { benar (tidak duplikat) }\end{array}$} \\
\hline $\begin{array}{l}\text { Sebagai PENERBIT saya ingin } \\
\text { fitur petunjuk penggunaan, agar } \\
\text { SAYA dapat melihat informasi } \\
\text { tentang cara menggunakan } \\
\text { aplikasi ini }\end{array}$ & $\begin{array}{l}\text { Sebagai PENERBI } \text { f ya ingin } \\
\text { fitur FREQUENTLY ASKED } \\
\text { QUESTIONS, agar SAYA dapat } \\
\text { melihat informasi tentang } \\
\text { informasi ini dengan jelas }\end{array}$ \\
\hline $\begin{array}{l}\text { Sebagai PENERBIT saya ingin } \\
\text { fitur informasi jenis dan size } \\
\text { file berkas syarat, agar SAYA } \\
\text { mengetahui jenis dan size file } \\
\text { yang akan diupload pada } \\
\text { menu berkas syarat }\end{array}$ & $\begin{array}{l}\text { Sebagai ADMIN saya ingin } \\
\text { menambahkan menu delete } \\
\text { data user operator, Agar } \\
\text { SAYA dapat menghapus data } \\
\text { user operator yang sudah } \\
\text { tidak aktif }\end{array}$ \\
\hline
\end{tabular}

Gambar 6. User Story pada aplikasi Trello

\subsection{Merencanakan Sprint}

DT dan PO berkolaborasi dalam tahap ini. Tujuan dari tahap ini adalah membuat Sprint Goal. DT mengerjakan Sprint Backlog dalam satu sprint dari PBI (diuraikan menjadi task) untuk mencapai Sprint Goal. Urutan Sprint yang sudah disepakati dan akan dijalankan oleh DT ada pada Tabel 8, 9,10, dan 11 .

Tabel 8. Sprint pertama menambahkan field atribut pada menu upload buku

\begin{tabular}{|c|c|c|c|}
\hline Sprint Backlog & Sprint Goal & Task & $\begin{array}{c}\text { Estimasi } \\
\text { Waktu } \\
\text { (Jam) }\end{array}$ \\
\hline \multirow{6}{*}{$\begin{array}{l}\text { Sebagai PENERBIT saya } \\
\text { ingin fitur isian formulir data } \\
\text { buku di atribut Jenis Buku, } \\
\text { tahun terbit, Jenjang } \\
\text { Pendidikan dan Kelas pada } \\
\text { menu upload buku } \\
\text { ditambahkan, agar SAYA } \\
\text { mengetahui informasi data } \\
\text { buku secara lengkap dan } \\
\text { jumlah data buku yang benar } \\
\text { (tidak duplikat) }\end{array}$} & $\begin{array}{l}\text { OPERATOR } \\
\text { Mendapatkan jumlah }\end{array}$ & $\begin{array}{l}\text { Create fungsi script dan table } \\
\text { atribut Jenis Buku }\end{array}$ & 4 \\
\hline & $\begin{array}{l}\text { data buku yang sesuai } \\
\text { dengan yang di-upload } \\
\text { oleh } \text { user penerbit }\end{array}$ & $\begin{array}{l}\text { Create fungsi script dan table } \\
\text { atribut Jenis Buku atribut tahun } \\
\text { terbit }\end{array}$ & 4 \\
\hline & & $\begin{array}{l}\text { Create fungsi script dan table } \\
\text { atribut Jenis Buku atribut Jenjang } \\
\text { Pendidikan }\end{array}$ & 4 \\
\hline & & $\begin{array}{l}\text { Create fungsi script dan table } \\
\text { atribut Jenis Buku atribut Kelas }\end{array}$ & 4 \\
\hline & & $\begin{array}{l}\text { Modifikasi Tampilan } \\
\text { Upload Buku }\end{array}$ & 4 \\
\hline & & Total & 20 \\
\hline
\end{tabular}


Tabel 9. Sprint kedua menambahkan menu panduan penggunaan dan frequently asked questions (FAQ)

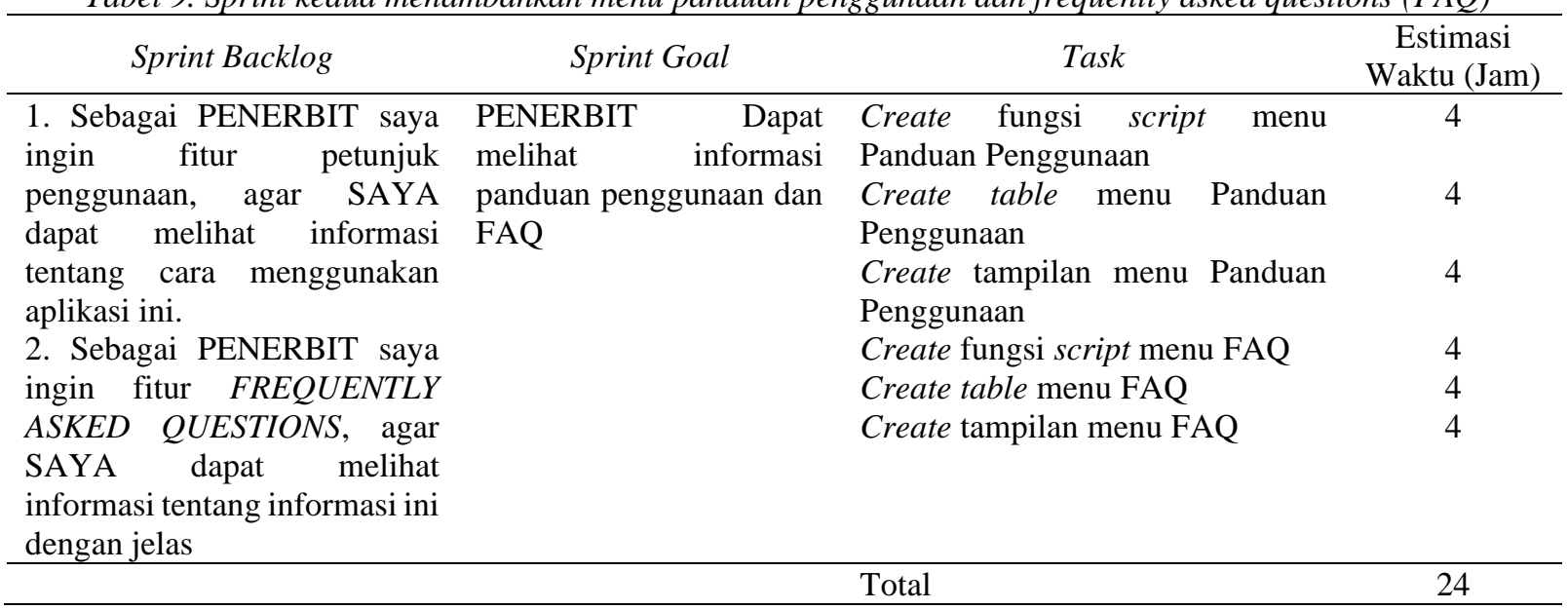

Tabel 10. Sprint ketiga menambahkan informasi jenis dan size file pada menu upload berkas

\begin{tabular}{lllc}
\hline \multicolumn{1}{c}{ Sprint Backlog } & \multicolumn{1}{c}{ Sprint Goal } & \multicolumn{1}{c}{ Task } & $\begin{array}{c}\text { Estimasi } \\
\text { Waktu } \\
\text { (Jam) }\end{array}$ \\
\hline $\begin{array}{l}\text { Sebagai PENERBIT saya } \\
\text { ingin fitur informasi jenis dan } \\
\text { size file berkas syarat, agar }\end{array}$ & $\begin{array}{l}\text { PENERBIT dapat melihat } \\
\text { informasi jenis dan size }\end{array}$ & $\begin{array}{l}\text { Create tampilan informasi jenis } \\
\text { fan size file yang akan di-upload }\end{array}$ & 6 \\
$\begin{array}{l}\text { SAYA mengetahui jenis dan } \\
\text { size file yang akan di-upload } \\
\text { pada menu berkas syarat }\end{array}$ & $\begin{array}{l}\text { user } \\
\text { Modifikasi script jenis dan size } \\
\text { upload file }\end{array}$ & 6 \\
\hline & Total & 12 \\
\hline
\end{tabular}

Tabel 11. Sprint keempat menambahkan menu delete data user operator pada user admin

\begin{tabular}{lllc}
\hline \multicolumn{1}{c}{ Sprint Backlog } & \multicolumn{1}{c}{ Sprint Goal } & \multicolumn{1}{c}{ Task } & $\begin{array}{c}\text { Estimasi } \\
\text { Waktu } \\
\text { (Jam) }\end{array}$ \\
\hline $\begin{array}{l}\text { Sebagai ADMIN saya ingin } \\
\text { menambahkan menu delete } \\
\text { data } \text { user } \text { operator, Agar }\end{array}$ & $\begin{array}{l}\text { ADMIN dapat menghapus } \\
\text { data dari operator }\end{array}$ & $\begin{array}{l}\text { Create script delete data } \\
\text { SAYA dapat menghapus data } \\
\text { user } \text { operator yang sudah }\end{array}$ & operator \\
tidak aktif & Modifikasi tampilan & 5 \\
\hline & & 4 \\
\hline
\end{tabular}

\subsection{Menjalankan Sprint dan Daily Scrum}

DT mengerjakan beberapa task pada Sprint Pertama dari yang sudah disepakati pada Sprint Backlog. Sprint ini dilakukan selama 20 hari dengan pengerjaan 5 task. Waktu pengerjaan yang diberikan untuk setiap task-nya adalah 4 jam. Sprint ini dilakukan selama 3 hari dari tanggal 6 April sampai dengan 8 April 2020. Berikut tampilan proses pengerjaan Sprint Pertama pada aplikasi Trello: 


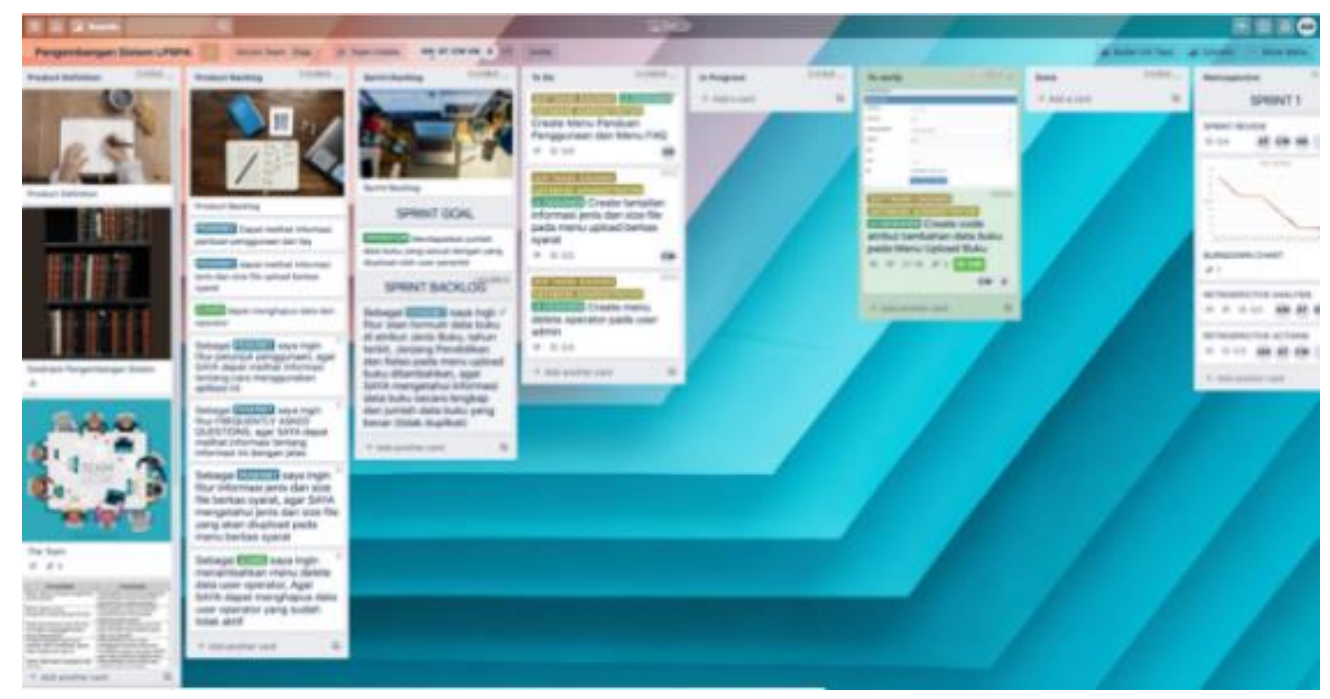

Gambar 7. Proses sprint pertama pada aplikasi Trello

DT menyelesaikan 1 jam lebih cepat dari Sprint Pertama. Berikut adalah Product Increment pada Sprint Pertama:

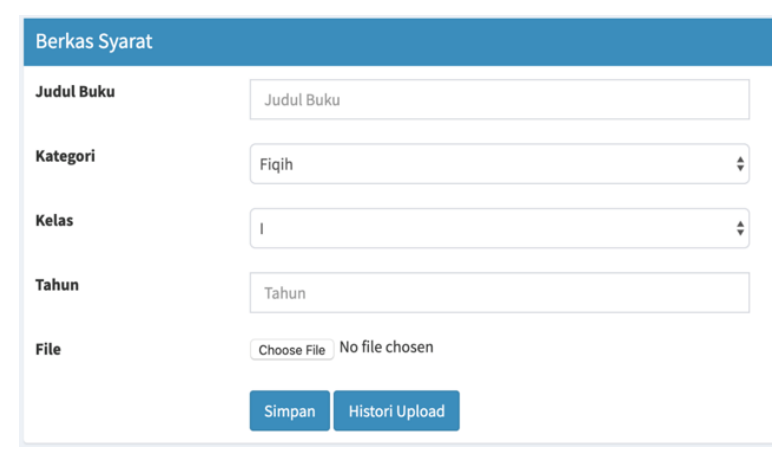

Gambar 8. Kolom formulir menu upload buku sebelum dikembangkan pada sistem

Pada Sprint Kedua DT mengerjakan 6 task yang sudah disepakati selama 24 jam. Target waktu pengerjaan dalam 1 task adalah 4 jam. Hari efektif pengerjaan Sprint ini adalah 3 hari.

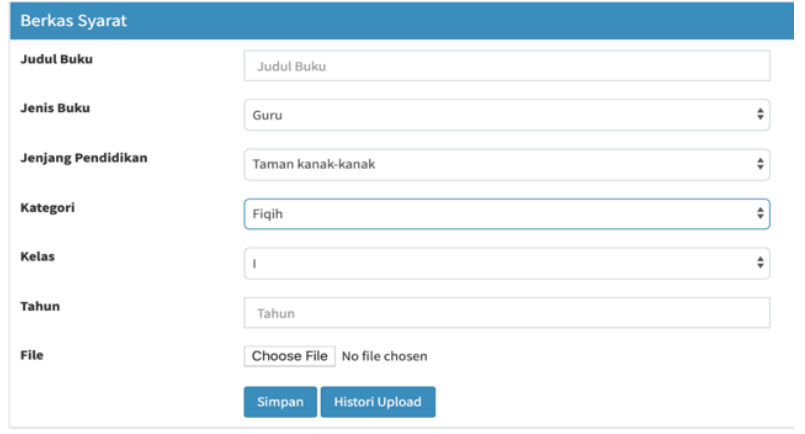

Gambar 9. Kolom formulir menu upload buku setelah dikembangkan pada sistem

3 hari lainnya adalah hari libur. Dimulai dari tanggal 9 April sampai dengan 14 April 2020. Berikut adalah tampilan proses pengerjaan Sprint Kedua pada aplikasi Trello: 


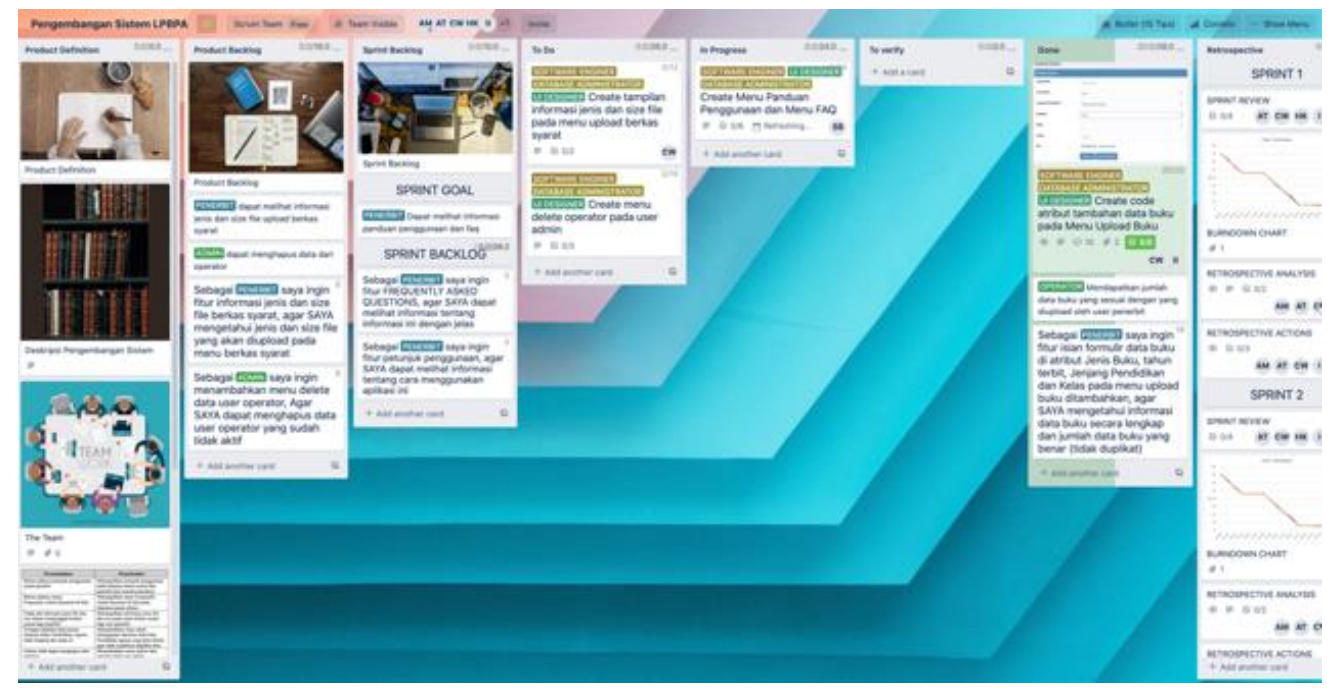

Gambar 10. Proses sprint kedua pada aplikasi Trello

Dalam menyelesaikan Sprint Kedua, DT melebihi target waktu yang sudah ditentukan yaitu lebih 2 jam. Dari waktu pengerjaan 24 jam jadi 26 jam. Namun Sprint Kedua sukses dijalankan dan diselesaikan dengan baik sehingga menghasilkan Product Increment sebagai berikut:

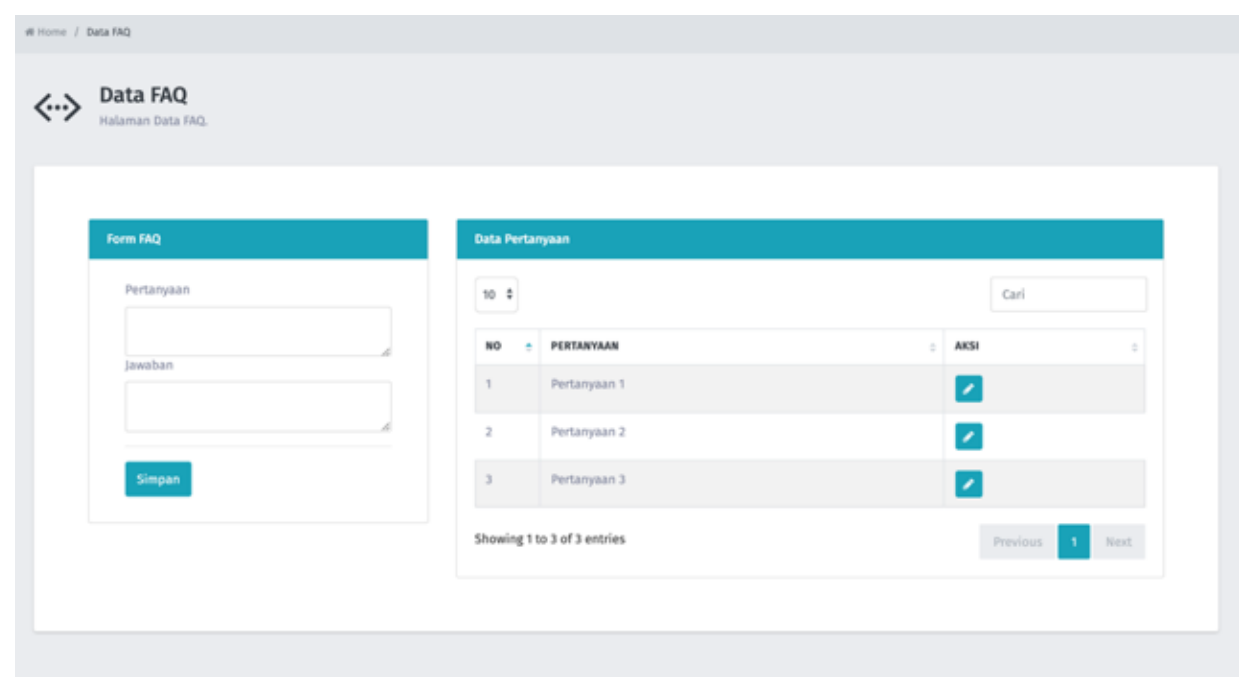

Gambar 11. Halaman backend hasil pengembangan menu FAQ 
LPBPA home sambutan buku berita pencaduan register MASYARAKAT

\section{FAQ}

Gara registrasi pada SisLPBPA dengan klilik menu Register ditop menu website halaman depan. Lalu kiuti langkah-langkah selanjutrnya

BAGAIMANA PROSES PENILAIAN BUKU PENDIDIKAN AGAMA DILAKUKAN?

BAGAIMANA TAHAP PENDAFTARAN DILAKUKAN?

Gambar 12. Halaman frontend hasil pengembangan menu FAQ

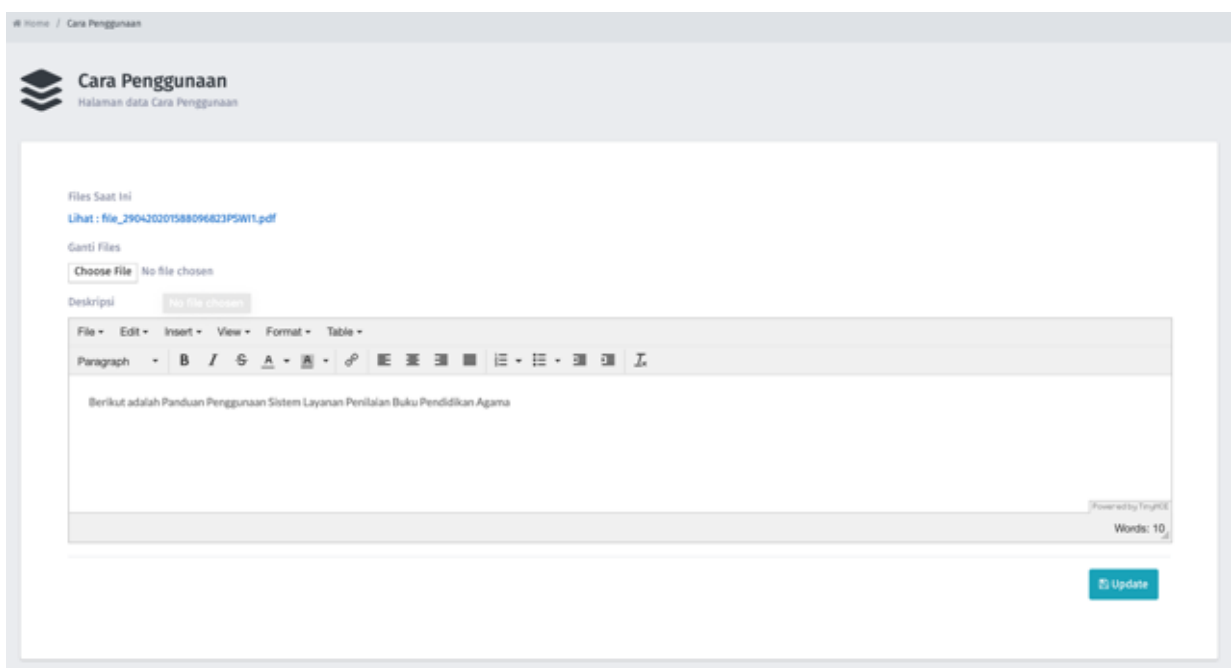

Gambar 13. Halaman backend hasil pengembangan menu cara penggunaan

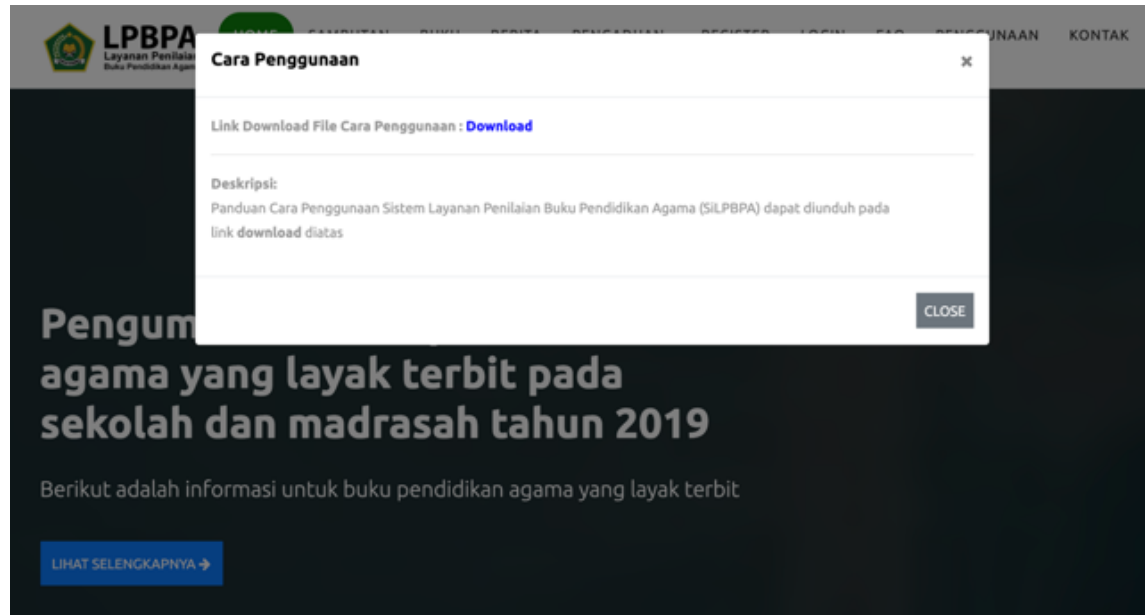

Gambar 14. Halaman frontend hasil pengembangan menu cara penggunaan 


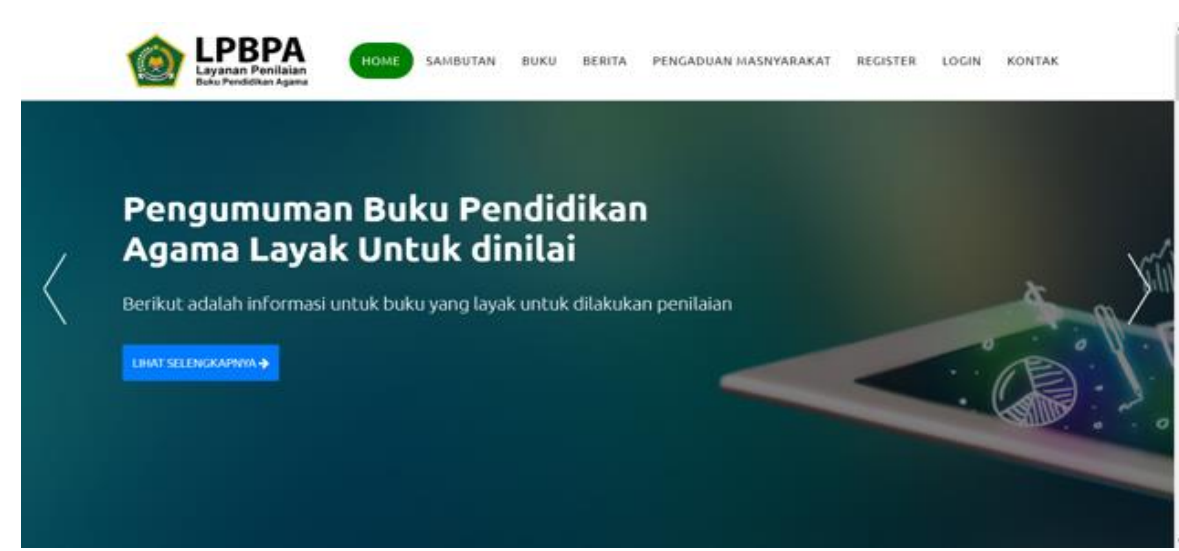

Gambar 15. Halaman frontend sebelum hasil pengembangan
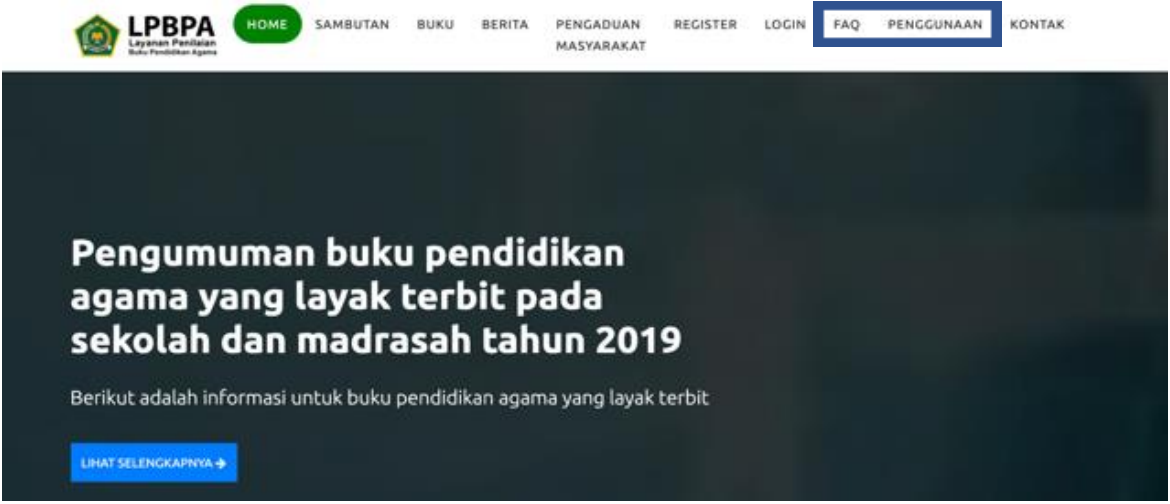

Gambar 15. Halaman frontend sesudah hasil pengembangan

Pada Sprint Ketiga, DT melakukan proses pengerjaan selama 2 hari dari tanggal 15 April sampai dengan 16 April 2020. Dengan target waktu 12 jam untuk 2 task. Berikut tampilan proses pengembangan sistem pada aplikasi Trello:

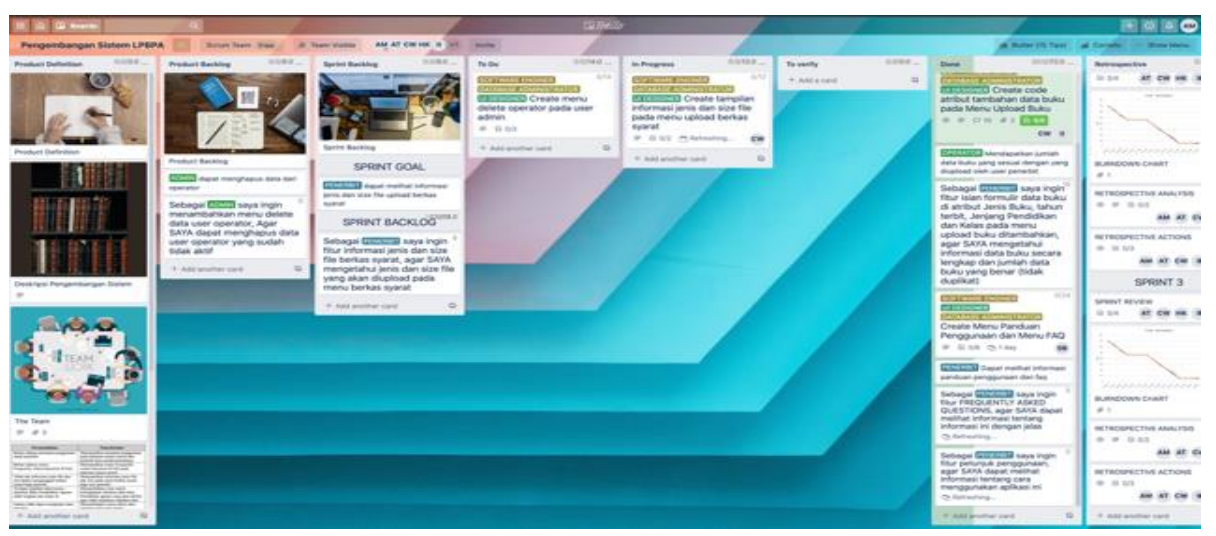

Gambar 16. Sprint ketiga pada aplikasi Trello

Pada Sprint ini, semua task diselesaikan lebih cepat 2 jam oleh DT dari target waktu yang telah ditentukan yaitu 10 jam, sehingga menghasilkan Product Increment sebagai berikut: 


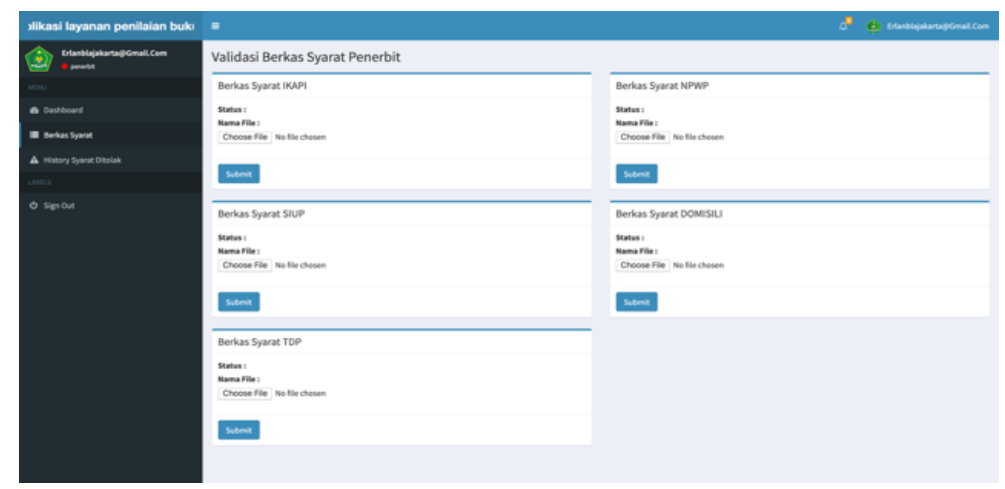

Gambar 17. Informasi jenis file dan size menu upload berkas syarat sebelum dikembangkan pada sistem

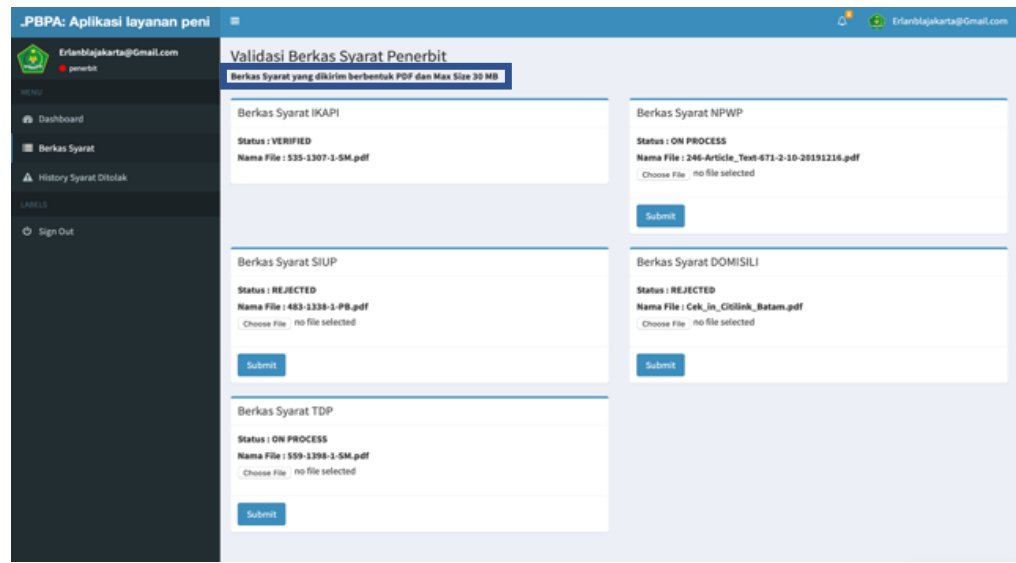

Gambar 18. Informasi jenis file dan size menu upload berkas syarat sesudah dikembangkan pada sistem

Sprint Keempat dilaksanakan dari tanggal 17 April sampai dengan 20 April 2020. Hari efektif kerja adalah 2 hari, sedangkan 2 harinya libur. Sprint ini merupakan Sprint terakhir dalam melakukan pengembangan SiLPBPA. Terdapat 3 task yang harus diselesaikan dengan target waktu 14 jam. 2 task target waktunya 10 jam sedangkan sisanya 1 task target waktu yang ditentukan 4 jam. Berikut tampilan proses pengerjaan Sprint Keempat pada aplikasi Trello:

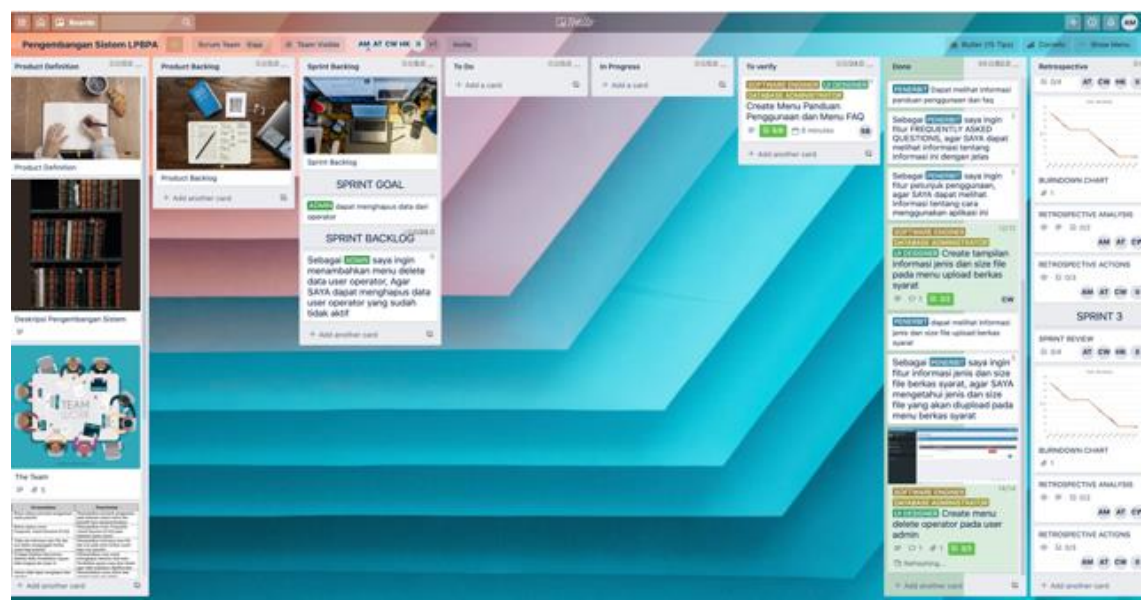

Gambar 19. Sprint keempat pada aplikasi Trello 
DT menyelesaikan semua task lebih cepat 4 jam dari target waktu yang sudah ditentukan yaitu 10 jam. Berikut adalah tampilan Product Increment yang dihasilkan pada tahap ini:

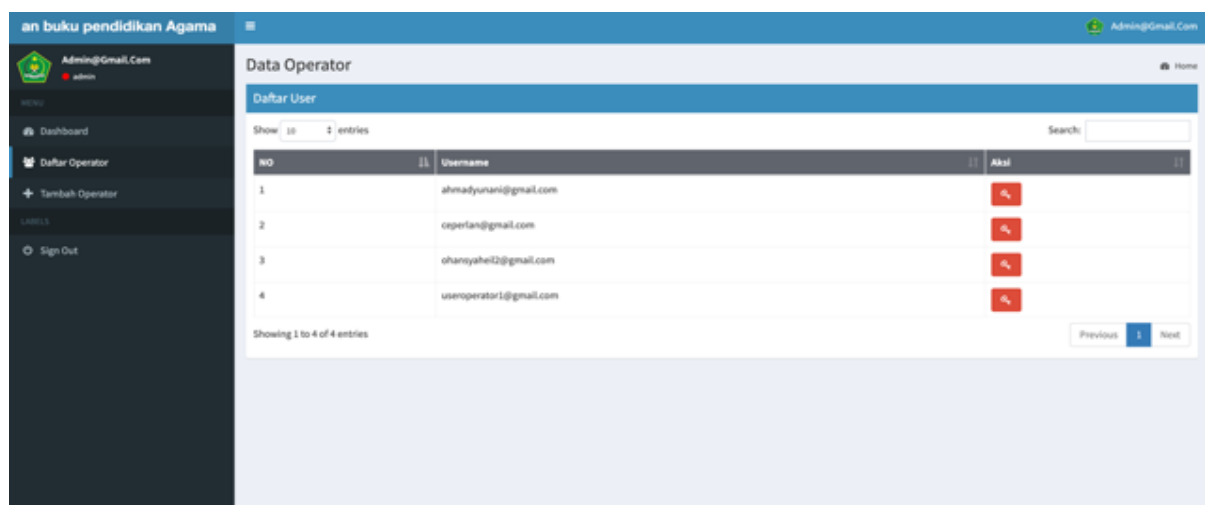

Gambar 20. Menu delete operator pada user admin sebelum dikembangkan

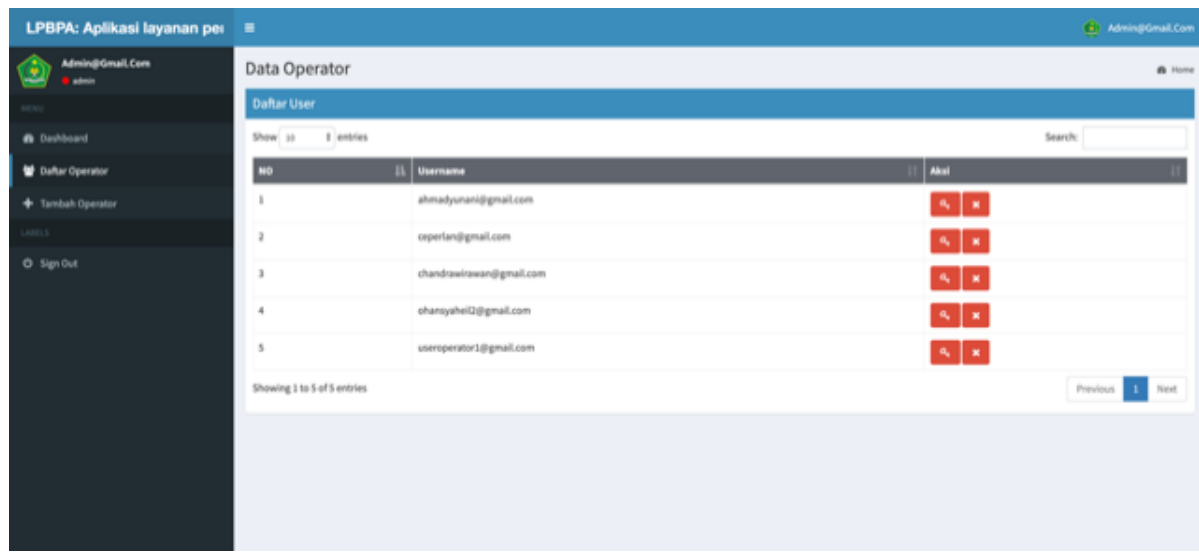

Gambar 20. Menu delete operator pada user admin sesudah dikembangkan

DT melakukan kegiatan Daily Scrum dengan durasi 15 menit selama Sprint Pertama sampai dengan Sprint Keempat berlangsung. Kegiatan ini dilakukan dengan pertemuan secara daring. Tujuannya untuk membahas apa saja yang sudah dilakukan, kendala kemarin dan merencanakan aktifitas sekarang.

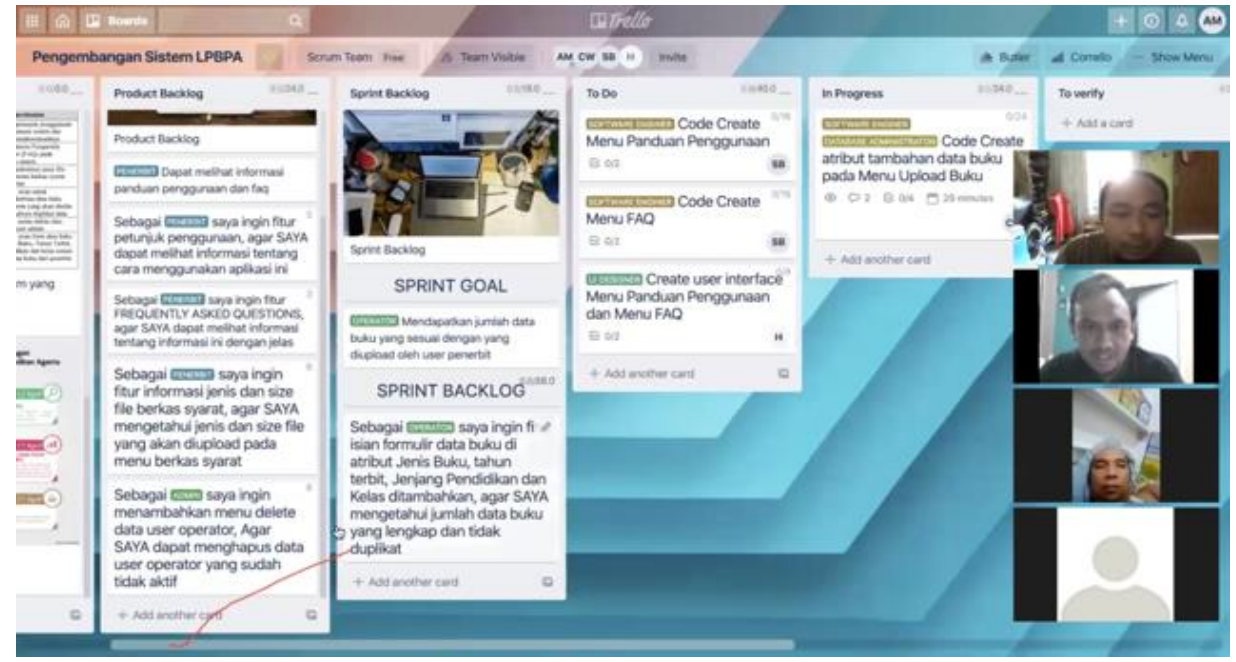

Gambar 21. Kegiatan daily scrum development team (DT) secara daring 


\subsection{Burndown Chart}

Burndown Chart memudahkan tim Scrum dalam mendapatkan informasi untuk melakukan evaluasi pada akhir sprint [29]. Rencana dan realisasi pekerjaan yang sudah dilakukan dapat dilihat dengan Burndown Chart. Penyelesaian jumlah sisa jam kerja ditunjukkan oleh sumbu X (Vertical) sedangkan hari-hari dalam menjalankan Sprint ditunjukkan oleh sumbu Y (Horizontal). Pembaharuan grafik dilakukan setiap hari pada pertemuan Daily Scrum oleh penggabungan estimasi sisa pekerjaan untuk semua task dalam Sprint Backlog. Garis biru pada Burndown Chart menunjukkan target waktu yang ditentukan sedangkan garis orange menunjukkan waktu yang terealisasi dari rencana yang ditentukan. Terlihat pada Gambar 22 bahwa jam kerja tidak sesuai dengan yang sudah ditentukan.

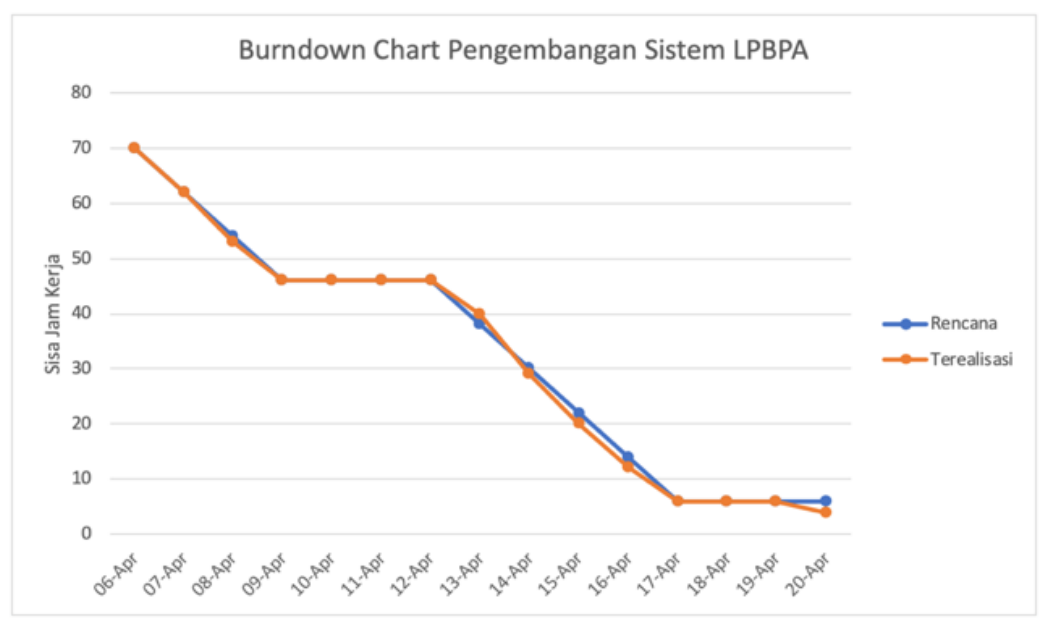

Gambar 22. Burndown chart pengembangan SiLPBPA

Tujuh puluh jam adalah target waktu untuk menyelesaikan pengembangan SiLPBPA ini. Dengan waktu efektif kerja adalah 10 hari dan 5 hari libur. Pada grafik, tanggal 13 April garis orange ada $\mathrm{di}$ atas garis biru karena penyelesaian pekerjaan lebih lambat 2 jam, sedangkan pada tanggal 8,14, 15, 14 dan 20 April, Garis biru ada di bawah garis orange karena penyelesaian pekerjaan lebih cepat 7 jam. Jadi total waktu untuk menyelesaikan pengembangan SiLPBPA Versi 1.0 ini adalah $65 \mathrm{jam}$.

\subsection{Melakukan Sprint Review dan Sprint Retrospective}

Sprint Review dilakukan setelah Product increment dihasilkan dalam satu Sprint. Tujuan kegiatan ini adalah melakukan pemeriksaan dan penyesuaian terhadap fitur produk yang dihasilkan dari PBI. Tim Scrum beserta Stakeholder (pengguna sistem) dalam pengembangan SiLPBPA versi 1.0 terlibat semua dalam kegiatan ini. DT melakukan demonstrasi dari fitur produk yang dihasilkan. Semua peserta melakukan review dan diskusi mengenai fitur-fitur yang dikembangkan Semua peserta menyetujui fitur-fitur tersebut untuk segera di-release. 


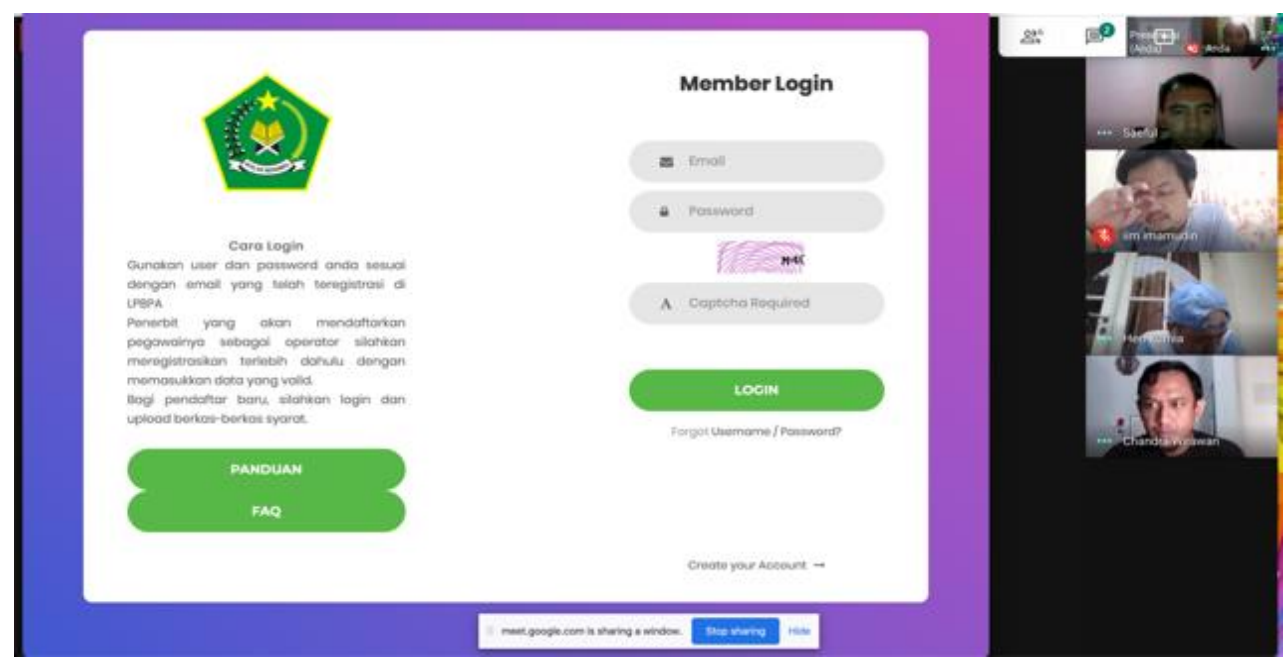

Gambar 23. Kegiatan sprint review secara daring

Kegiatan Sprint Retrospective dilaksanakan setelah Sprint Review yang dihadiri hanya oleh tim Scrum. Dalam pertemuan ini dibahas hambatan-hambatan yang terjadi selama satu Sprint. Hambatan yang terjadi ketika melakukan pengembangan SiLPBPA adalah lebih lambat 2 jam waktu pengerjaan pada Sprint Kedua ditanggal 13 April 2020. Hal ini terjadi karena adanya kesalahan komunikasi pada DT. Tim melakukan diskusi untuk menemukan solusi agar ke depannya tidak terjadi pada sprint selanjutnya.

\section{PENUTUP}

Berdasarkan hasil penelitian yang telah dilakukan maka dapat disimpulkan hasil pengujian usability menggunakan SUS dengan 14 responden mendapatkan hasil skor SUS ratarata 71. Ada pada Predikat C, Kategori Acceptable, dan dengan Rating Good. Artinya sistem ini hanya bisa digunakan untuk kegiatannya. Namun, ketika diimplementasikan SiLPBPA perlu dilakukan pengembangan. Hal ini dibuktikan dengan adanya beberapa saran dari pengguna pada hasil kuesioner. Saran dari user tersebut kemudian diidentifikasi permasalahan dan dibuat penyelesaiannya. Pengembangan sistem dilakukan dengan kerangka kerja Scrum. Scrum terbukti memiliki tingkat keberhasilan yang tinggi dalam pengembangan sistem ini. Hal ini terlihat pada Burndown Chart. Target waktu yang ditentukan adalah 70 jam dapat selesai hanya dalam waktu 65 jam. Kemudian Product Increment yang dihasilkan pada semua Sprint sudah memenuhi kebutuhan pengguna. Hal ini Terlihat pada kegiatan Sprint Review, semua peserta (Tim Scrum dan pengguna sistem) menyetujui hasilnya. Sehingga SiLPBPA dapat diimplementasikan pada kegiatan layanan penilaian buku Pendidikan Agama selanjutnya. Namun, untuk mengetahui tingkat keberhasilan implementasi sistem yang sudah dikembangkan perlu dilakukan penelitian analisis kualitas usability kembali. Ke depannya SiLPBPA ini perlu dilakukan pengembangan lebih lanjut. Terutama untuk fitur pengelolaan user keseluruhan, Integrasi Backend dengan Frontend, Pengelolaan Data Buku Pendidikan Agama, pengelolaan laporan akhir buku layak dinilai dan buku layak diterbitkan dan proses penilaian BPA di dalam sistem.

\section{DAFTAR PUSTAKA}

[1] Kementerian Agama Republik Indonesia, Peraturan Menteri Agama Republik Indonesia Nomor 9 Tahun 2018 Tentang Buku Pendidikan Agama. Indonesia, 2018, pp. 1-11.

[2] Badan Litbang dan Diklat Kemenag Republik Indonesia, Keputusan Kepala Badan Penelitian Dan Pengembangan Dan Pendidikan Dan Pelatihan Kementerian Agama Republik Indonesia Nomor 51 Tahun 2018 Tentang Penulisan, Penilaian, Dan Penerbitan Buku Pendidikan Agama. Indonesia, 2019, pp. 1-32.

[3] B. Pudjoatmodjo and R. Wijaya, "Tes kegunaan (usability testing) pada aplikasi kepegawaian dengan menggunakan system usability scale," Semin. Nas. 
Teknol. Inf. dan Multimed. 2016, pp. 3742.

[4] D. Setiawan, S. L. Wicaksono, and N. Rafianto, "Evaluasi usability e-learning moodle dan google classroom menggunakan SUS quisionnare," JAMI J. Ahli Muda Indonesia., vol. 1, no. 1, Mei 2020, pp. 55-64.

[5] A. W. Soejono, et al., "Evaluasi usability website unriyo menggunakan system usability scale (studi kasus: website Unriyo)," J. Teknol. Inf., vol. 13, no. 1, 2018, pp. 29-37.

[6] W. U. Martoyo and Falahah, "Kajian evaluasi usability dan utility pada situs web," in Seminar Nasional Sistem Informasi Indonesia, 2015, no. 2-3, November 2015, pp. 537-544.

[7] U. Ependi, T. B. Kurniawan, and F. Panjaitan, "System usability scale vs heuristic evaluation: a review," Simetris J. Tek. Mesin, Elektro dan Ilmu Komput., vol. 10, no. 1, 2019, pp. 65-74.

[8] R. V. Anand and M. Dinakaran, "Popular agile methods in software development: review and analysis," Int. J. Sci. Tech. Adv., vol. 2, no. 4, 2016, pp. 147-150.

[9] K. Schwaber and J. Sutherland, Panduan Scrum, no. November. 2017.

[10] D. Murdiani, A. Yudhana, and S. Sunardi, "Implementasi agile method dalam pengembangan jurnal elektronik di lembaga penelitian non-pemerintahan (nGo)," J. Teknol. Inf. dan Ilmu Komput., vol. 7, no. 4, p. 709, 2020.

[11] W. Warkim, et al., "Penerapan metode scrum dalam pengembangan sistem informasi layanan kawasan," J. Tek. Inform. dan Sist. Inf., vol. 6, no. 2, 2020, pp. 365-378.

[12] H. Hutrianto and A. Putra, "Implementasi scrum model dalam pengembangan aplikasi pelaporan sampah sebagai wujud smart cleaning," JIPI (Jurnal Ilm. Penelit. dan Pembelajaran Inform.), vol. 5, no. 1, 2020, pp. 9-19.

[13] R. A. Azdy and A. Sn, "Implementasi scrum pada pengembangan software terdistribusi," in Seminar Nasional Informatika 2012 (Semnas IF 2012) UPN "Veteran" Yogyakarta, Volume 1 No 2 2012: Network and Security, p. B-32-B37, 2012.

[14] P. A. G. Permana, "Scrum method implementation in a software development project management," Int. J. Adv. Comput. Sci. Appl., vol. 6, no. 9, 2015, pp. 198-204.

[15] E. S. F. Cardozo, et al, "Scrum and productivity in software projects: A systematic literature review," in 14th International Conference on Evaluation and Assessment in Software Engineering (EASE) (EASE), 2010, pp. 1-4.

[16] H. Harjono and M. Hamka, "Implementasi framework scrum dalam pengembangan sistem informasi jabatan fungsional akademik," in Seminar Nasional Hasil - Hasil Penelitian Dan Pengabdian Pada Masyarakat III Tahun 2017 "Pengembangan sumber daya menuju masyarakat madani berkearifan lokal," 2018, December 2017, pp. 239244.

[17] J. Partogi, Manajemen Modern dengan Scrum-Sebuah Petualangan Baru di Abad 21 Menjadi Manajer Software Development Modern. Yogyakarta: Penerbit ANDI, 2015.

[18] Z. Sharfina and H. B. Santoso, "An Indonesian adaptation of the System Usability Scale (SUS)," 2016 Int. Conf. Adv. Comput. Sci. Inf. Syst. ICACSIS 2016, 2017, pp. 145-148.

[19] H. N. I. Aprilia, P. I. Santoso, and R. Ferdiana, "Pengujian usability website menggunakan system usability scale," J. IPTEKKOM J. Ilmu Pengetah. Teknol. Inf., vol. 17, no. 1, 2015, pp. 31-38.

[20] E. Susilo, "Cara menggunakan system usability scale (SUS) pada evaluasi usability," 2019. [Online]. Available: https://www.edisusilo.com/caramenggunakan-system-usability-scale/. [Accessed: 14-Mar-2020].

[21] J. Brooke, SUS: A "Quick and dirty" Usability Scale, 1st ed. London: Taylor and Francis, 1996.

[22] J. Brooke, "SUS: a retrospective," J. Usability Stud., vol. 8, no. 2, 2013, pp. 29-40.

[23] J. Sauro, "Measuring usability with the System Usability Scale (SUS)," Measuring U, 2011. [Online]. Available: https://measuringu.com/sus/. [Accessed: 25-Sep-2019].

[24] U. Efendi and Q. Widayati, "Extreme programming study method case study on designing of accounting term 
dictionary," in The Third International

Conference On Engineering And Technology Development, 2014, pp. 116.

[25] A. Bangor, P. Kortum, and J. Miller, "Determining what individual SUS scores mean: adding an adjective rating scale," J. Usability Stud., vol. 4, no. 3, 2009, pp. 114-123.

[26] K. S. Rubin, "Essential scrum: A practical guide to the most popular agile process," 2nd ed. New Jersey: Pearson Education, 2013.

[27] J. Sauro, "Does better usability increase customer loyalty?," in Measuring U, 2010. [Online]. Available: https://measuringu.com/usabilityloyalty/. [Accessed: 20-Mar-2020].

[28] L. Moon, "The top trello tips for beginners to boost productivity," 2020 .
[29] M. A. Firdaus, "Implementasi kerangka kerja scrum pada manajemen pengembangan sistem informasi," s, vol. 1, no. 2, 2017, pp. 283-288.

\section{Hak Cipta}

Semua naskah yang tidak diterbitkan, dapat dikirimkan di tempat lain. Penulis bertanggung jawab atas ijin publikasi atau pengakuan gambar, tabel dan bilangan dalam naskah yang dikirimkannya. Naskah bukanlah naskah jiplakan dan tidak melanggar hak-hak lain dari pihak ketiga. Penulis setuju bahwa keputusan untuk menerbitkan atau tidak menerbitkan naskah dalam jurnal yang dikirimkan penulis, adalah sepenuhnya hak Pengelola. Sebelum penerimaan terakhir naskah, penulis diharuskan menegaskan secara tertulis, bahwa tulisan yang dikirimkan merupakan hak cipta penulis dan menugaskan hak cipta ini pada pengelola. 